\title{
The Hawaiian freshwater algae biodiversity survey (2009-2014): systematic and biogeographic trends with an emphasis on the macroalgae
}

Alison R Sherwood ${ }^{1 *}$, Amy L Carlile ${ }^{1,2}$, Jessica M Neumann ${ }^{1}$, J Patrick Kociolek ${ }^{3}$, Jeffrey R Johansen ${ }^{4}$, Rex L Lowe ${ }^{5}$, Kimberly Y Conklin ${ }^{1}$ and Gernot G Presting ${ }^{6}$

\begin{abstract}
Background: A remarkable range of environmental conditions is present in the Hawaiian Islands due to their gradients of elevation, rainfall and island age. Despite being well known as a location for the study of evolutionary processes and island biogeography, little is known about the composition of the non-marine algal flora of the archipelago, its degree of endemism, or affinities with other floras. We conducted a biodiversity survey of the non-marine macroalgae of the six largest main Hawaiian Islands using molecular and microscopic assessment techniques. We aimed to evaluate whether endemism or cosmopolitanism better explain freshwater algal distribution patterns, and provide a baseline data set for monitoring future biodiversity changes in the Hawaiian Islands.

Results: 1,786 aquatic and terrestrial habitats and 1,407 distinct collections of non-marine macroalgae were collected from the islands of Kauai, Oahu, Molokai, Maui, Lanai and Hawaii from the years 2009-2014. Targeted habitats included streams, wet walls, high elevation bogs, taro fields, ditches and flumes, lakes/reservoirs, cave walls and terrestrial areas. Sites that lacked freshwater macroalgae were typically terrestrial or wet wall habitats that were sampled for diatoms and other microalgae. Approximately 50\% of the identifications were of green algae, with lesser proportions of diatoms, red algae, cyanobacteria, xanthophytes and euglenoids. 898 DNA sequences were generated representing eight different markers, which enabled an assessment of the number of taxonomic entities for genera collected as part of the survey. Forty-four well-characterized taxa were assessed for global distribution patterns. This analysis revealed no clear biogeographic affinities of the flora, with 27.3\% characterized as "cosmopolitan", 11.4\% "endemic", and 61.3\% as intermediate.
\end{abstract}

Conclusions: The Hawaiian freshwater algal biodiversity survey represents the first comprehensive effort to characterize the non-marine algae of a tropical region in the world using both morphological and molecular tools. Survey data were entered in the Hawaiian Freshwater Algal Database, which serves as a digital repository of photographs and micrographs, georeferenced localities and DNA sequence data. These analyses yielded an updated checklist of the non-marine macroalgae of the Hawaiian Islands, and revealed varied biogeographic affinities of the flora that are likely a product of both natural and anthropogenic dispersal.

Keywords: Algal distribution, Biodiversity survey, Biogeography, Cyanobacteria, Dispersal, Freshwater algae, Hawaiian Islands, Molecular characterization, Taxonomy, UPA

\footnotetext{
* Correspondence: asherwoo@hawaii.edu

'Department of Botany, University of Hawaii, 3190 Maile Way, Honolulu, HI 96822, USA

Full list of author information is available at the end of the article
}

\section{Biomed Central}

(c) 2014 Sherwood et al.; licensee BioMed Central Ltd. This is an Open Access article distributed under the terms of the Creative Commons Attribution License (http://creativecommons.org/licenses/by/4.0), which permits unrestricted use, distribution, and reproduction in any medium, provided the original work is properly credited. The Creative Commons Public Domain Dedication waiver (http://creativecommons.org/publicdomain/zero/1.0/) applies to the data made available in this article, unless otherwise stated. 


\section{Background}

Eight main islands and 124 small islands, atolls and shoals comprise the Hawaiian Archipelago, which encompasses $16,640 \mathrm{~km}^{2}$ and represents the largest oceanic archipelago in the world [1,2]. The islands are volcanically-derived, and form successively as the Pacific Plate moves in a northwestern direction over a fixed "hot spot", such that the eight current high islands (The Main Hawaiian Islands) at the southeastern end of the chain represent only the last 5.1 million years (my) of a 75-80 my history of volcanic activity [3]. The Main Hawaiian Islands are characterized by steep gradients of elevation $(0-4,200 \mathrm{~m})$, rainfall $(25-1,050 \mathrm{~cm} /$ year) and island age (0-5.1 my), which have generated a remarkable range of ecological conditions [2,4].

The Hawaiian Islands are well known as a uniquely isolated and time-calibrated environment in which to study evolution; a place where numerous lineages of plants and animals exemplify the phenomena of endemism and adaptive radiation [5-9]. The geographical isolation of the Main Hawaiian Islands $(>3,500 \mathrm{~km}$ from the nearest continent) is a strong force influencing the biogeography of Hawaii, and initial colonization of the islands was accomplished through the arrival and survival of dispersed individuals [1]. Subsequent colonization likely occurred through a combination of long-distance dispersal, and, increasingly commonly, dispersal from adjacent islands [3].

A number of studies on the freshwater algae of the Hawaiian Islands have appeared in the literature [10-20]. Eight hundred taxonomic records were compiled from the literature in a bibliographic checklist spanning the years 1876-2003 [21], which included representatives of almost all major freshwater algal lineages. Based on these literature records (which are almost exclusively based on morphospecies identifications), the overall level of endemism for the Hawaiian non-marine algae was estimated to be $5 \%$, or a total of 40 taxa. This endemism level was noted as being very low in comparison to other organisms such as marine red algae (20\%), marine invertebrates (32\%), ferns and lycophytes (74\%), flowering plants (79\%), and insects $(94 \%)[4,9,22]$. It was subsequently noted that the stream algal flora of Hawaii was "suspiciously cosmopolitan" in composition [23], drawing attention to the large proportion of Hawaiian taxonomic records in common with very different biogeographic regions of the world. Others have noted that freshwater algae around the world have often been considered to be cosmopolitan, that this notion is unlikely to hold true when tested with genetic data, and that endemism is most likely obscured by the "force-fitting" of European names [24].

Competing explanations exist for the biogeographic distributions of freshwater algae. Distributions of microbial algae can be examined in the context of "Everything is everywhere, but, the environment selects" [25], which predicts that microorganisms are globally distributed as a result of their vast population sizes and unlimited dispersal, and whether or not a species becomes established is determined solely by local conditions $[26,27]$. In contrast, a number of researchers have reported evidence of biogeographic patterning of microorganisms by using larger sample sizes, detailed observations, and/or molecular assessments of diversity [28-32], and still others invoke a combination of ubiquity and endemism to explain cryptic molecular lineages of widespread morphospecies [33,34]. Whether Hawaiian freshwater algae are truly cosmopolitan when molecular comparisons are taken into account, or whether they display levels of endemism that parallel other elements of the flora and fauna of the archipelago, is currently unknown.

Given current estimates of biodiversity loss, it is critical to understand the scope of endemism versus cosmopolitanism in the poorly characterized freshwater flora of a region already recognized as a biodiversity hotspot for other lineages of organisms. Loss of biodiversity is proceeding faster in freshwaters than in any other major biome [35-37]. The Hawaiian Freshwater Algal Biodiversity Survey (2009-2014) was carried out to establish baseline data to further assess human impacts on freshwater Hawaiian ecosystems and monitor change in the context of biodiversity conservation. The goals of the survey were to collect, document, and characterize as many non-marine algal taxa as possible from the Main Hawaiian Islands, and to use the resultant data to examine distribution patterns and develop biogeographic hypotheses to explain these patterns. The first author (ARS) held responsibility for the characterization of the macroalgal samples resulting from the survey, and as such the focus of the present report is on these taxa. Expeditionary collections were made on the islands of Kauai, Oahu, Molokai, Lanai, Maui and Hawaii, and macroalgal specimens were characterized morphologically and, where possible, using molecular methods. The distributional patterns and biogeographic affinities of taxa based on both literature records and DNA sequence analyses were examined in the context of distributions characterized by cosmopolitanism (as defined by reported presence in most other regions of the world) versus endemism (as defined by a lack of records outside the Hawaiian Islands). With very little information currently available for biogeographic patterns of specific freshwater algae based on molecular data trends, no predictions of biogeographic affinity were made for the Hawaiian nonmarine algae. However, an increase in the number of recognized endemic taxa was predicted, given the frequency with which freshwater algae are demonstrated to harbor cryptic (only revealed at the molecular level) diversity or pseudocryptic (not immediately evident at the morphological level but in retrospect discernable once the species boundaries are highlighted with molecular data) diversity when molecular tools are employed. 


\section{Results}

\section{Summary of collections}

A total of 1,786 distinct sites were sampled ("environmental accessions") (Figure 1). Collection sites were concentrated on the wetter, windward sides of the islands, and on the larger islands that had a greater number of perennial streams and associated moist habitats. Sampling sites were not chosen randomly, but were selected on the basis of accessibility and likelihood of harboring interesting algal diversity; thus, the following numbers should be interpreted as a summary of the characteristics of the collections rather than an indication of available habitats in the Hawaiian Islands. Areas not sampled lacked suitable habitats or were not accessible. Streams comprised $49.0 \%$ of all sites, followed by terrestrial sites $(17.1 \%)$ and wet walls $(12.5 \%)$, with smaller proportions of the remaining habitat categories (Figure 2a). A total of 2,823 isolate accessions (i.e. separate algal identifications) were characterized, of which 1,407 were macroalgae. Slightly more than $50.0 \%$ of these isolate accessions were green algae, while diatoms (38.8\%), red algae $(5.5 \%)$, cyanobacteria (2.9\%), xanthophytes (1.6\%) and euglenoids (0.7\%) comprised the remainder (Figure $2 \mathrm{~b}$ ). Additional file 1 summarizes the taxa identified, along with their islands of distribution and the habitat types from which they were collected and identified. The most widely collected taxa included the green algae Spirogyra spp. (300 accessions), Mougeotia spp. (144 accessions), Oedogonium spp. (102 accessions), Cladophora glomerata (89 accessions), Microspora spp. (78 accessions), Cloniophora spicata (69 accessions), and Rhizoclonium spp. (64 accessions), the red algal species Compsopogon caeruleus (34 accessions) and the xanthophyte Vaucheria spp. (31 accessions).

\section{DNA barcoding}

A total of 898 DNA sequences were generated as part of the survey, representing eight different markers (Figure 2c) [GenBank accessions for those sequences not previously published: KM676560 - KM676564 for ITS, KM676565 KM676567 for tufA, KM676568 - KM676828 for UPA, KM676829 - KM676881 for LSU, KM676882 - KM677026 for SSU, KM677027 - KM677127 for $r b c L]$. The UPA marker, which was employed as an initial screen for all samples, accounted for more sequences than any other marker (364 total), while SSU (203), rbcL (174), LSU (57), COI (53) and 16S rRNA (35) comprised the majority of the remainder.

Sequence data for the $16 \mathrm{~S}$ rRNA, COI, LSU, SSU, $r b c L$, and UPA markers were employed to investigate the molecular diversity of specific lineages of the Hawaiian nonmarine algal flora. Sequence diversity for each sampled taxon is represented in neighbor-joining trees based on uncorrected p-distances (Figures 3, 4, 5, 6, 7, 8, 9, 10, 11, 12, 13 and 14). Rather than attempting to reconstruct phylogenetic relationships for each taxon, we aimed to use these data for an assessment of patterns of molecular diversity within the Hawaiian flora. Thus, higher order relationships are not inferred from these analyses; comparisons should be restricted to closely-related taxa. More in-depth phylogenetic analyses have been published or are in progress for

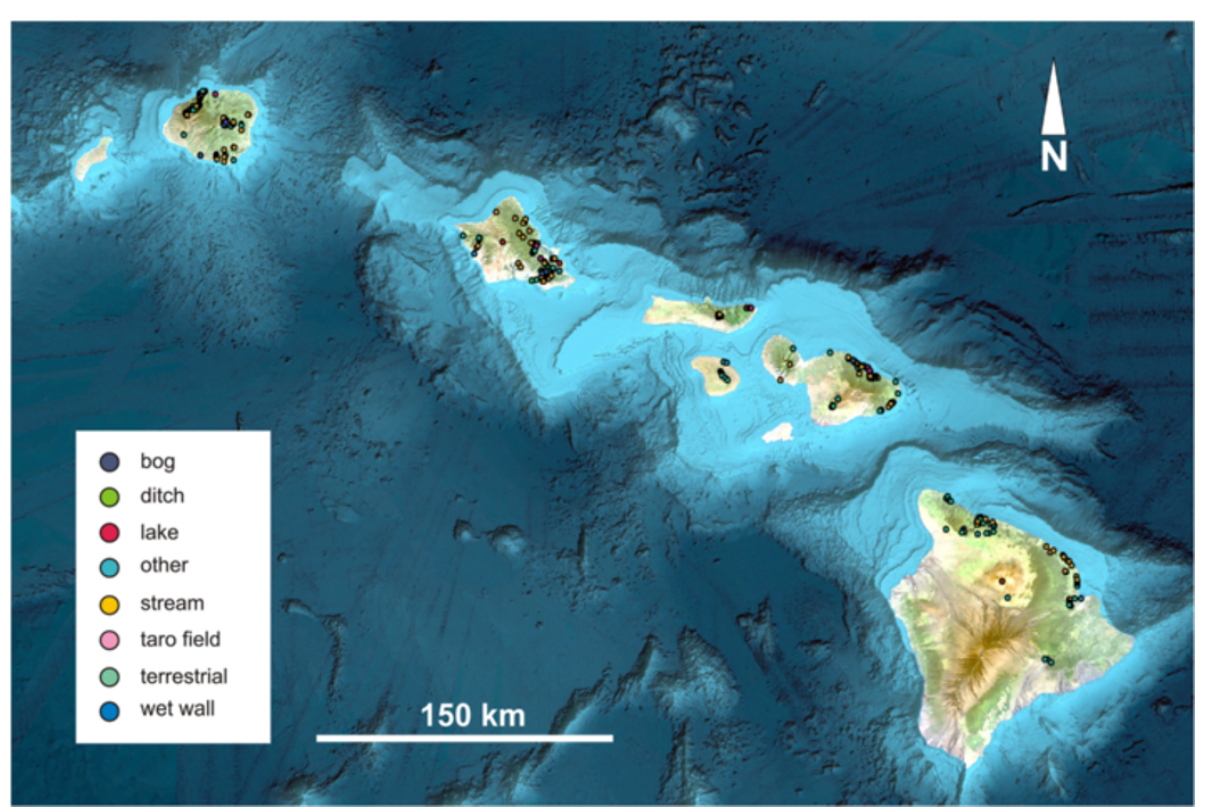

Figure 1 Map of collection sites. The 1,786 locations, or "environmental accessions" sampled as part of the Hawaiian Freshwater Algal Biodiversity Survey. Habitat types are coded by color (legend on figure). 

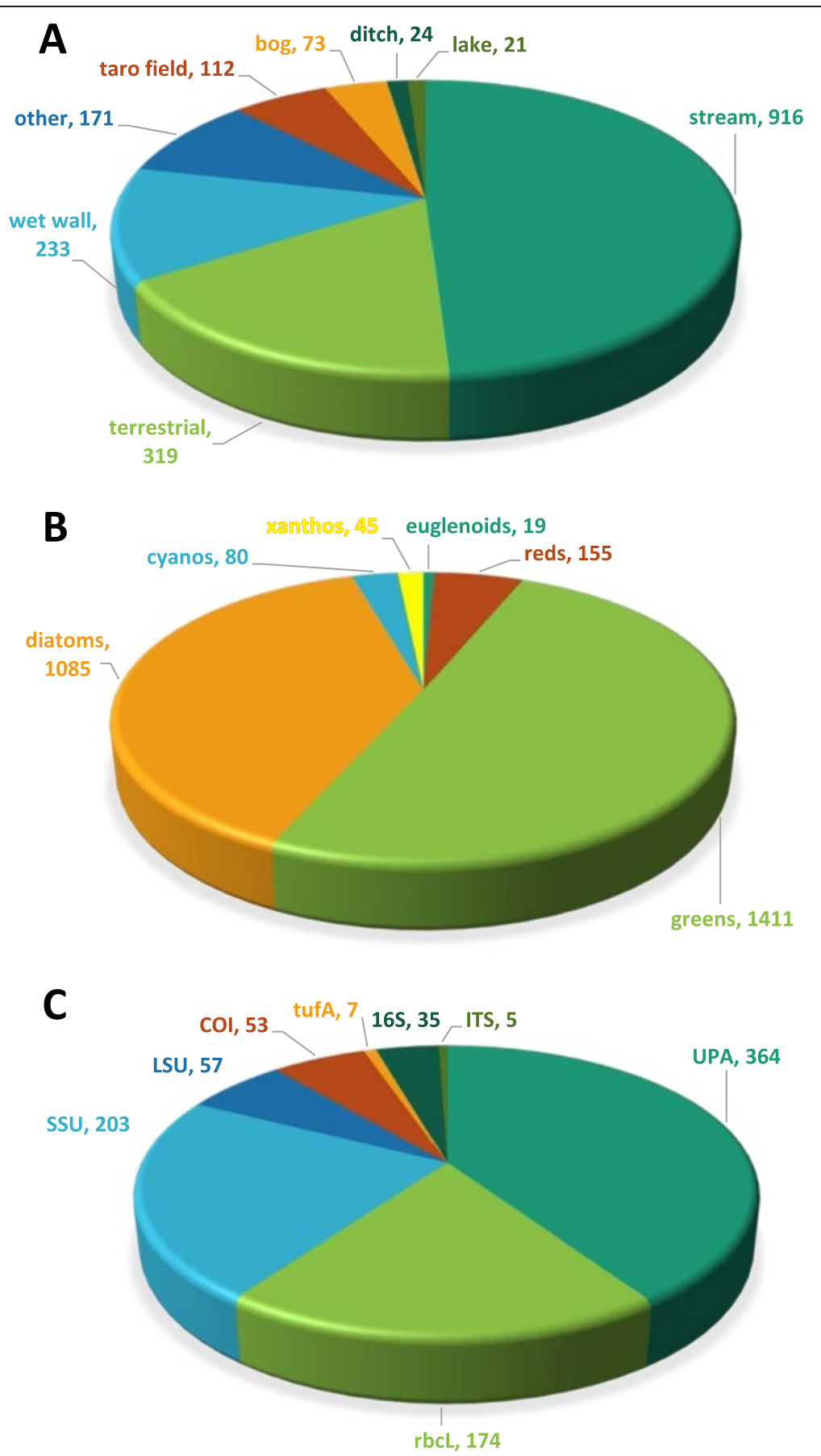

Figure 2 Summary statistics for the Hawaiian freshwater algal biodiversity survey. Summary statistics from the biodiversity survey. A) proportion and number of total environmental accessions represented by each habitat type, B) proportion and number of total isolate accessions represented by each major algal lineage, $\mathbf{C}$ ) proportion and number of total DNA sequences generated represented by each molecular marker.

a number of taxa, including green and red algae [38,39], cyanobacteria [40] and diatoms [41].

Summary taxon labels on each tree reflect the lowest taxonomic level to which a confident assignment can be made for a cluster of identical or near-identical sequences (i.e. those for which only single nucleotide differences were found, with the exception of those taxa known to harbor greater diversity, such as Sheathia arcuata). The vast majority of samples were not reproductive at the time of collection, which limited the number of taxa that could be identified to the species level. Nonetheless, clustering patterns of closely related sequences can be used as an 


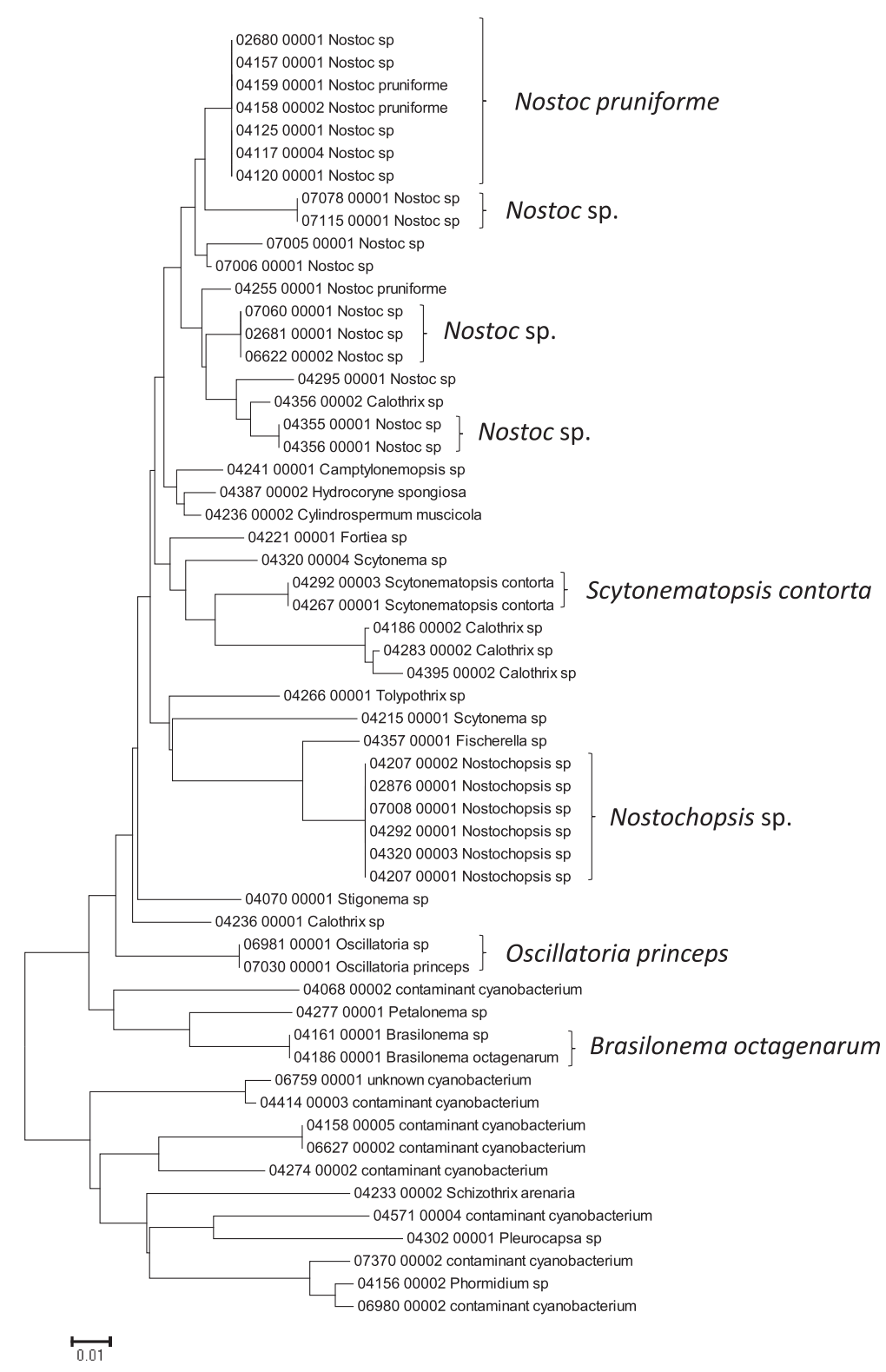

Figure 3 Neighbor-joining tree of UPA sequences of the Hawaiian non-marine cyanobacteria. Sequence diversity based on the UPA marker for Hawaiian cyanobacterial specimens. The neighbor-joining tree is based on uncorrected p-distances nucleotide model in MEGA 5.05 . Scale bar = substitutions per site.

indication of the number of entities represented in the Hawaiian flora for a given genus (at least for the commonly encountered entities). For example, the UPA analysis of cyanobacteria suggests eight species of the genus Nostoc were collected and characterized during the surveys (Figure 3), two of which were included in the 16S rRNA analysis (Figure 7). Four species of the red algal form genus "Chantransia" were identified from the UPA analysis, representing members of the Batrachospermales and Thoreales (Figure 4) [39], and these species-level groupings were consistent with groups recovered in the COI (Figure 8), $r b c L$ (Figure 11) and SSU (Figure 12) analyses.
The most species-rich genus of freshwater macroalgae studied in this survey was the charophycean green alga Spirogyra, which was demonstrated to consist of 12 clusters of sequences for the UPA marker (Figure 6), 13 for $r b c L$ (Figure 10), and nine for SSU (Figure 14); an in-depth comparison of these sequences to accessions worldwide and a comparative analysis of thallus morphology is underway (J. Neumann and A. Sherwood, personal observations).

\section{Categories of distribution}

The best-studied and best-represented taxa from the survey were examined for distributional trends: eight red 


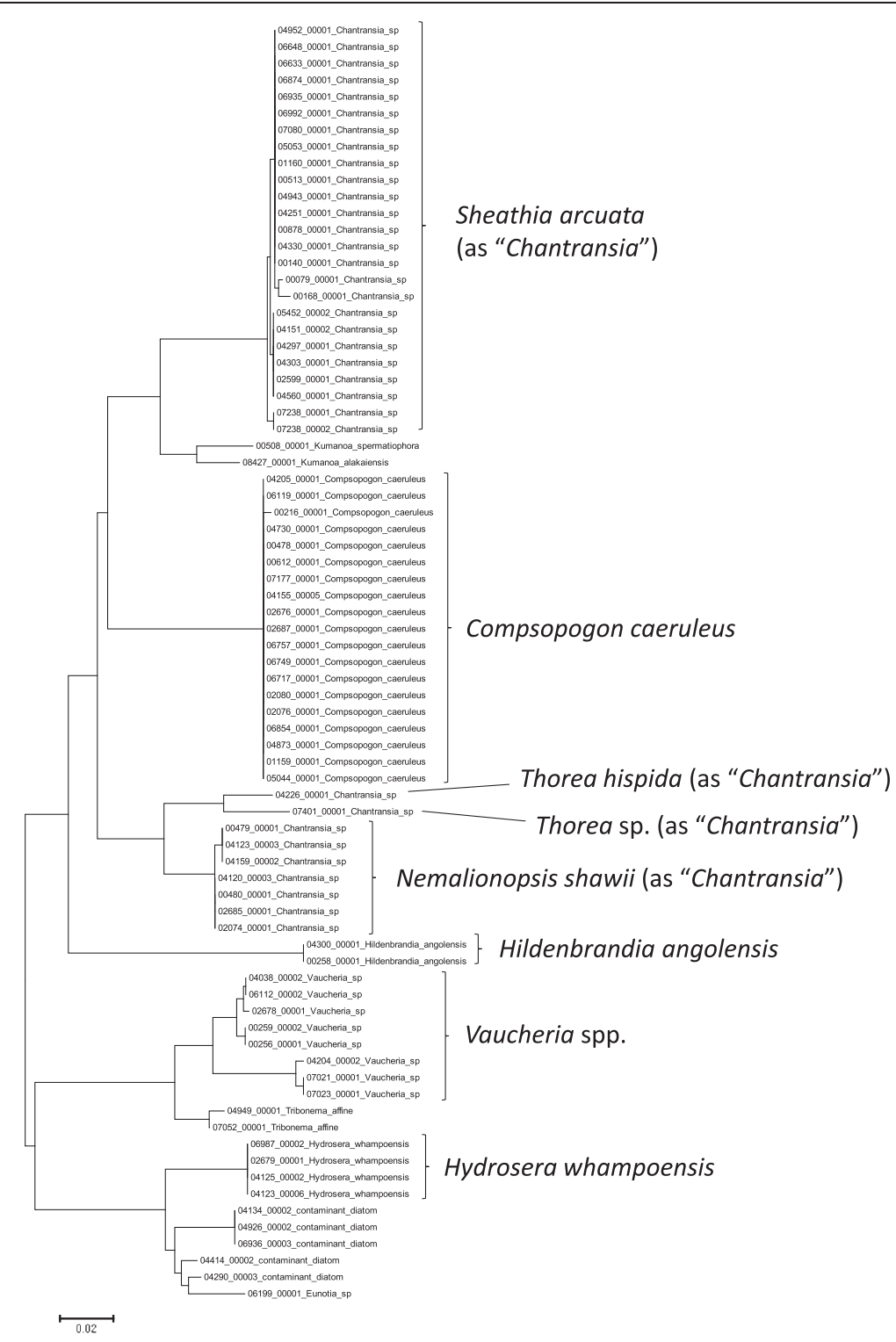

Figure 4 Neighbor-joining tree of UPA sequences of the Hawaiian non-marine red algae, diatoms and xanthophyte algae. Sequence diversity based on the UPA marker for the Hawaiian non-marine red algae, diatoms and xanthophytes. The neighbor-joining tree is based on uncorrected p-distances nucleotide model in MEGA 5.05. Scale bar = substitutions per site.

algae, 17 green algae, 14 cyanobacteria, four diatoms and one xanthophyte, for a total of 44 taxa (Figure 15). Twelve taxa were determined to be in the category of broadest distribution (mostly green algae, but also including some red algae and cyanobacteria), 17 were in the category of second most broadly distributed (all groups except xanthophytes), 10 were members of the third category (all groups except xanthophytes), and five were members of the putatively endemic category (three red algae and two cyanobacteria). It should be noted, however, that sampling effort has not been consistent among these regions of the world, with some having received many times the effort (e.g. Europe, North America) than others (e.g. Africa, Pacific Islands) over the course of the past several centuries.

For each of the taxa in each of the categories above, thallus size and dispersal unit size ranges (as determined from the literature) were plotted to assess patterns associated with dispersal category. Thallus sizes were found to range from microscopic to macroscopic for representatives of all dispersal categories (although not necessarily for all individual taxa) (Figure 16). In contrast, dispersal unit size ranges were found to be uniformly $\leq 1 \mathrm{~mm}$, and much smaller for both endemic and cosmopolitan taxa (Figure 17) (Additional file 2 contains a list of ordered taxonomic names for Figures 16 and 17). 


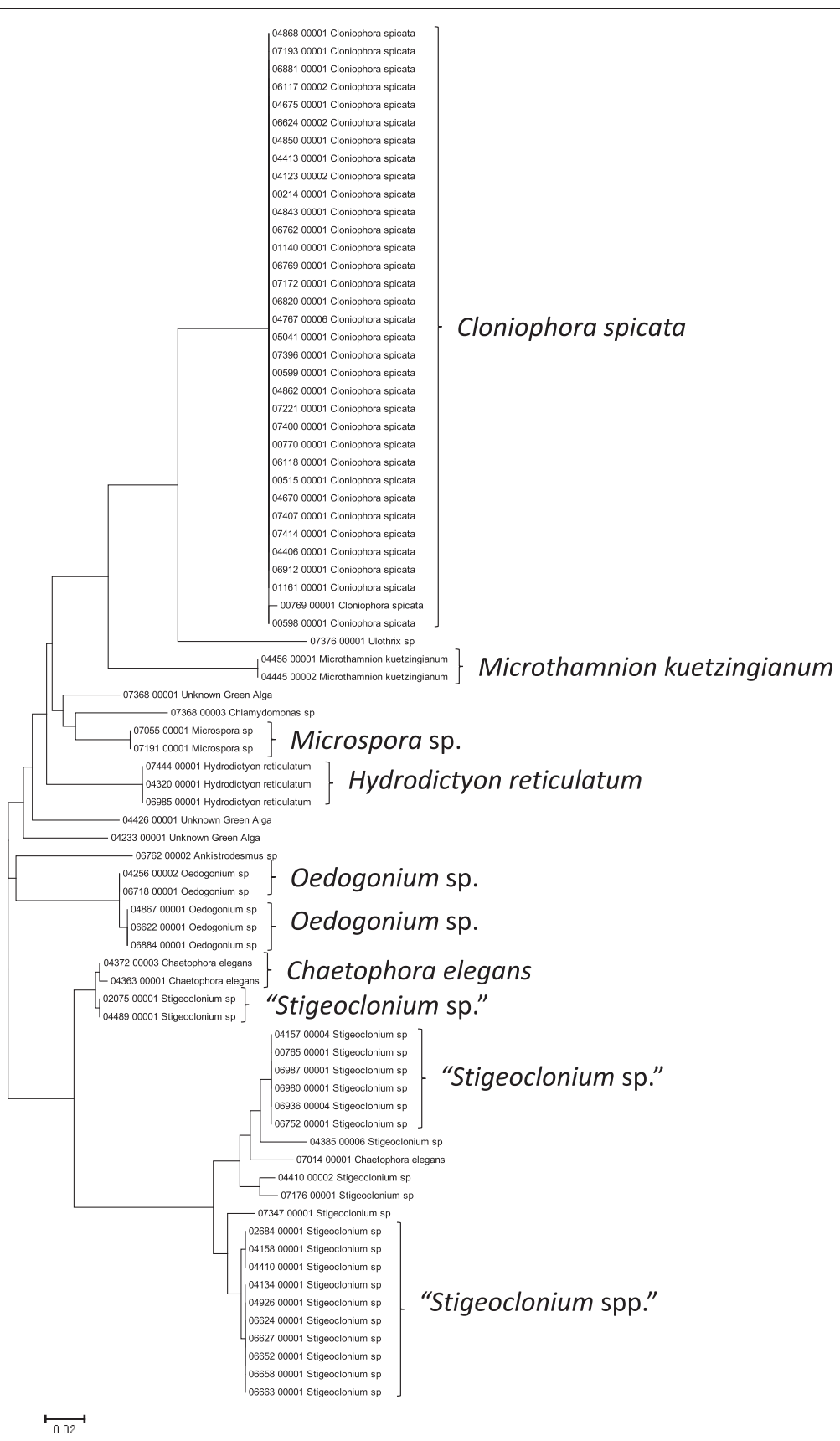

Figure 5 Neighbor-joining tree of UPA sequences of the Hawaiian non-marine, non-charophycean green algae. Sequence diversity based on the UPA marker for the Hawaiian non-marine, non-charophycean green algae. The neighbor-joining tree is based on uncorrected p-distances nucleotide model in MEGA 5.05. Scale bar= substitutions per site.

\section{Discussion}

\section{A comparative overview of the Hawaiian non-marine} macroalgal flora

The 1,407 macroalgal samples collected during the Hawaiian Freshwater Algal Biodiversity Survey represent, by far, the most exhaustive survey of non-marine algae for a tropical oceanic island archipelago yet reported. Previous studies in the tropical Pacific have yielded between seven and 167 samples, and have resulted in algal checklists of 12-160 taxa [20,42-47]. Algal studies of the islands of Yap, in the Caroline Islands, revealed a diverse flora of cyanobacteria, green algae, red algae, euglenoids and dinoflagellates totaling 63 taxa $[42,43]$, while, in contrast, a study of stream macroalgae of the islands of Fiji suggested an impoverished stream algal diversity of 15 taxa representing cyanobacteria, 


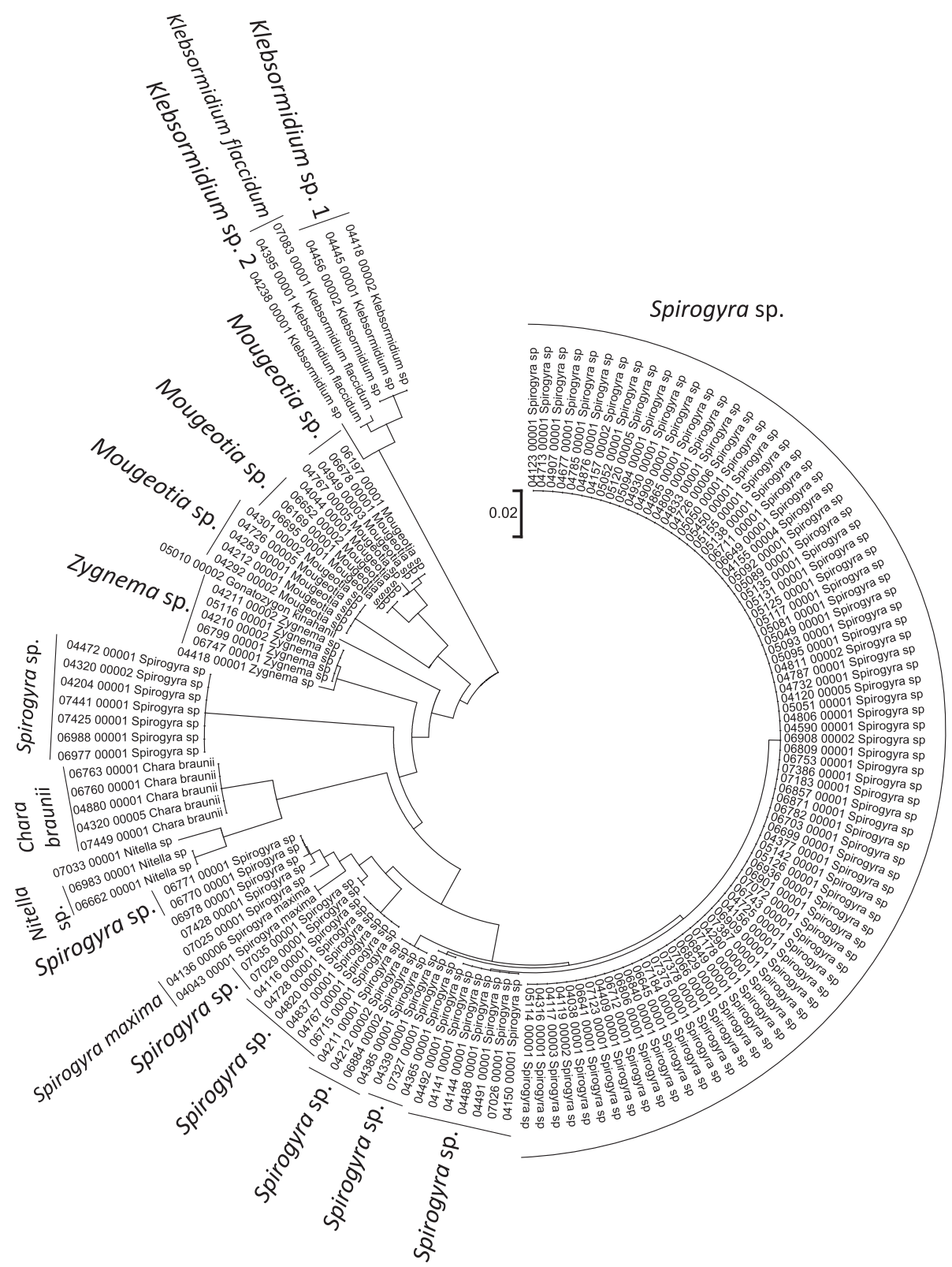

Figure 6 Neighbor-joining tree of UPA sequences of the Hawaiian non-marine charophycean green algae. Sequence diversity based on the UPA marker for the Hawaiian non-marine, charophycean green algae. The neighbor-joining tree is based on uncorrected p-distances nucleotide model in MEGA 5.05. Scale bar= substitutions per site.

green algae and red algae [44]. Similar to the flora from Fiji, a rapid survey of fresh waters from the Austral Islands of French Polynesia yielded 12 species, representing cyanobacteria, green algae and xanthophytes [46].

A number of previous studies of Hawaiian stream algae have been conducted, which yielded from 34 taxa [20] to 42 taxa [45] to 160 taxa [47]; albeit all identifications from these past studies were morphologically based, and thus are not completely comparable to the current research, and were also more limited in collection intensity. For example, many of the common taxa previously reported from the Hawaiian Islands have been subsequently demonstrated through molecular analyses to represent different, but recognized species (e.g. Cloniophora plumosa from Hawaii is now recognized to be C. spicata [38]), endemic Hawaiian taxa (e.g. collections of the cyanobacterium Nostochopsis), or members of different genera (previous Hawaiian records of the green algal genus Basicladia appear to now be attributable to Rhizoclonium [48]; and this study. All previous previous records of the red alga Audouinella from freshwaters 


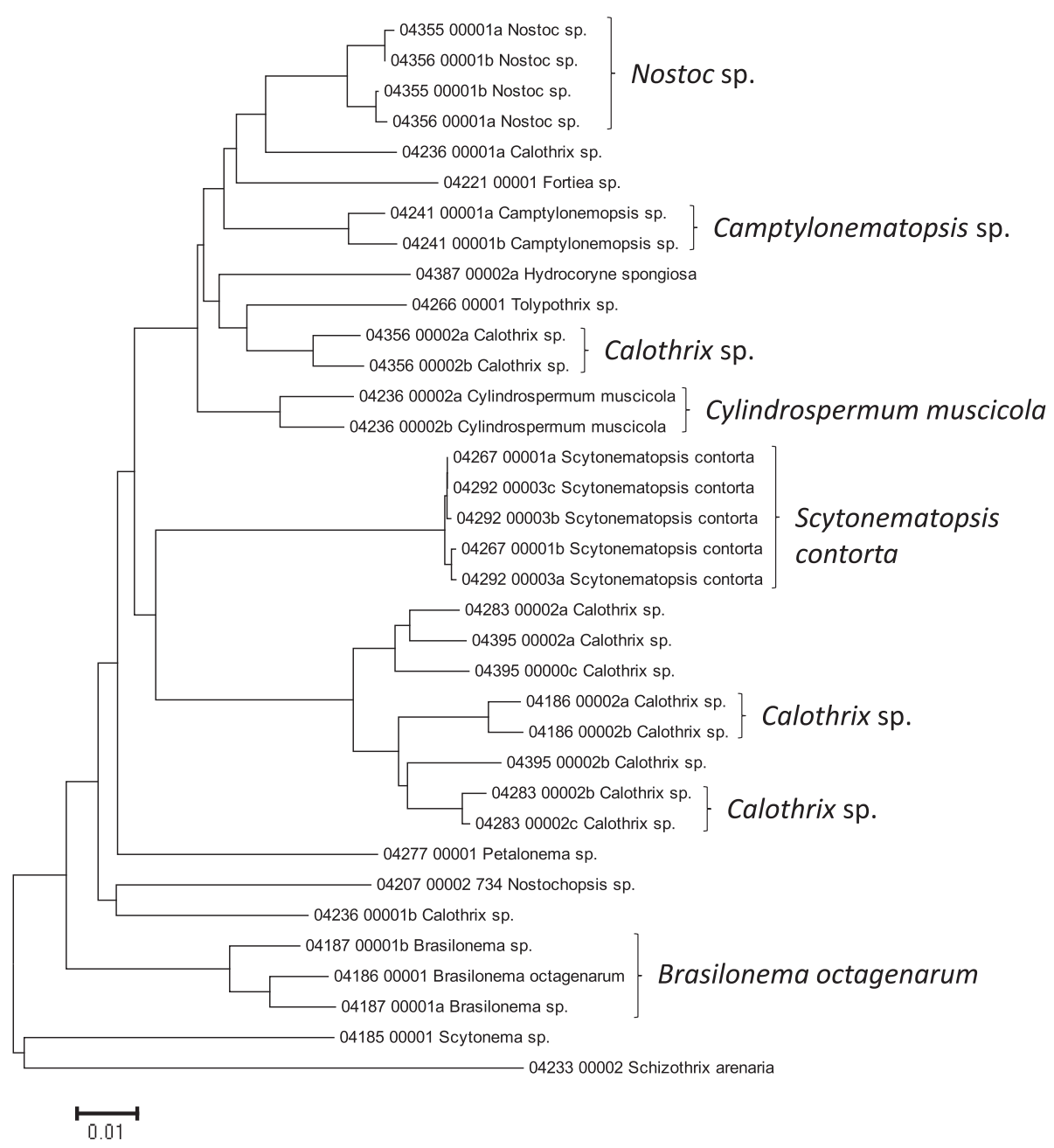

Figure 7 Neighbor-joining tree of 16S rRNA gene sequences of the Hawaiian non-marine cyanobacteria. Sequence diversity based on the 16S rRNA marker for the Hawaiian non-marine cyanobacteria. The suffixes "a", "b" or " $c$ " after an accession name indicate clone isolates of that sample. The neighbor-joining tree is based on uncorrected p-distances nucleotide model in MEGA 5.05. Scale bar= substitutions per site.

are now believed to represent sporophyte life history stages of the Batrachospermales and Thoreales in Hawaii [39]).

The present study is the first to integrate taxonomic collections from a multitude of non-marine algal habitats, including streams, wet walls, high elevation bogs, taro fields, ditches and flumes, cave walls and terrestrial areas for a tropical island algal flora. Two of these habitats were sufficiently well represented in the present survey collections to warrant individual treatment, and these have been published elsewhere as reports on the non-marine algae of Hawaiian taro fields [49] (which differ in being characterized by slow or absent water movement and higher temperatures than nearby streams) and high elevation bogs [50] (which are unique habitats in the Hawaiian Islands characterized by a high degree of isolation, low $\mathrm{pH}$, high rainfall, and lower temperatures than many of the other sampled habitats).
Molecular markers and example within-lineage patterns A total of eight different molecular markers were employed in this study to characterize the non-marine algal diversity of the Hawaiian Islands. Due to the large scope of phylogenetic diversity encompassed in the collections (e.g. cyanobacteria as well as multiple eukaryotic algal lineages), we aimed to establish a multi-step molecular assessment that allowed initial broad-based characterization of all collections (based on the UPA marker), with subsequent use of one or more lineage-specific markers (e.g. 16S, COI, tufA, ITS, LSU, $r b c L$ [51-58]) for comparisons among closely related samples. Our previous biodiversity survey of the Hawaiian Rhodophyta (red algae $[59,60]$ ) as well as other algal investigations [61-66] have provided support for the use of the UPA marker as a near-universal region of the plastid genome that enables construction of a molecular biodiversity framework for almost all algae, and we 


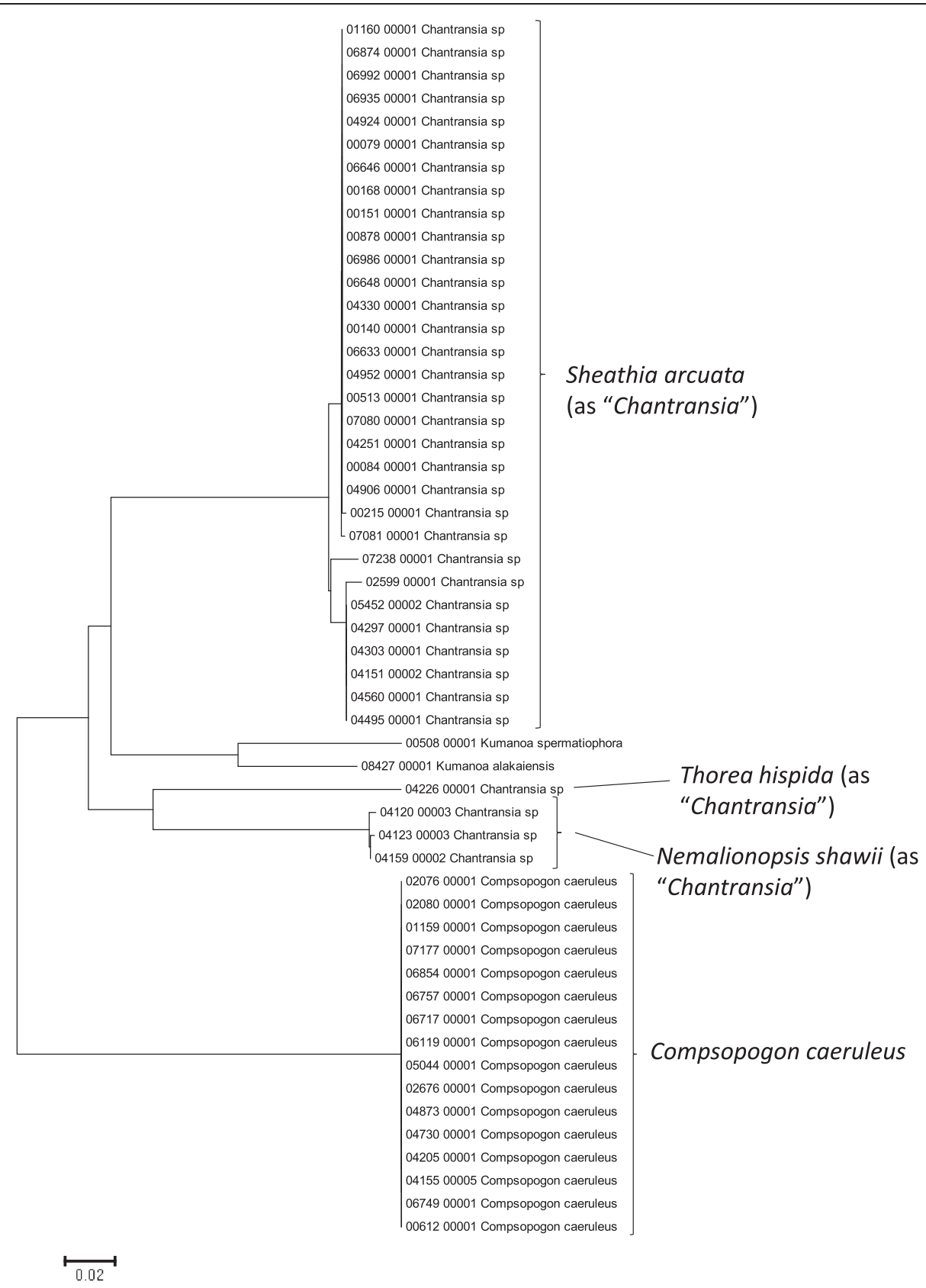

Figure 8 Neighbor-joining tree of $\mathrm{COI}$ sequences of the Hawaiian non-marine red algae. Sequence diversity based on the COI marker for the Hawaiian non-marine red algae. The neighbor-joining tree is based on uncorrected p-distances nucleotide model in MEGA 5.05. Scale bar = substitutions per site.

advocate for the use of this marker in multi-step molecular characterizations or analyses of environmental DNA samples where characterization of both cyanobacterial and eukaryotic algal diversity is desirable. Our second most widely applied marker, which spans the V4 region of nuclear SSU $[67,68]$, also resulted in generation of a large number of sequences, albeit fewer than UPA and of a more conserved nature than that marker (and also lacking in cyanobacterial representation). A comparison of the use of both markers for the characterization of environmental DNA from stream periphyton is underway (A. Carlile, R. Kodner \& A. Sherwood, personal communication).

A number of taxa were well-represented in the survey, and the Hawaiian biodiversity represented by these lineages was characterized using a combination of the molecular approaches described above and microscopic analysis. For example, the charophycean genus Spirogyra has been noted as one of the most common freshwater 


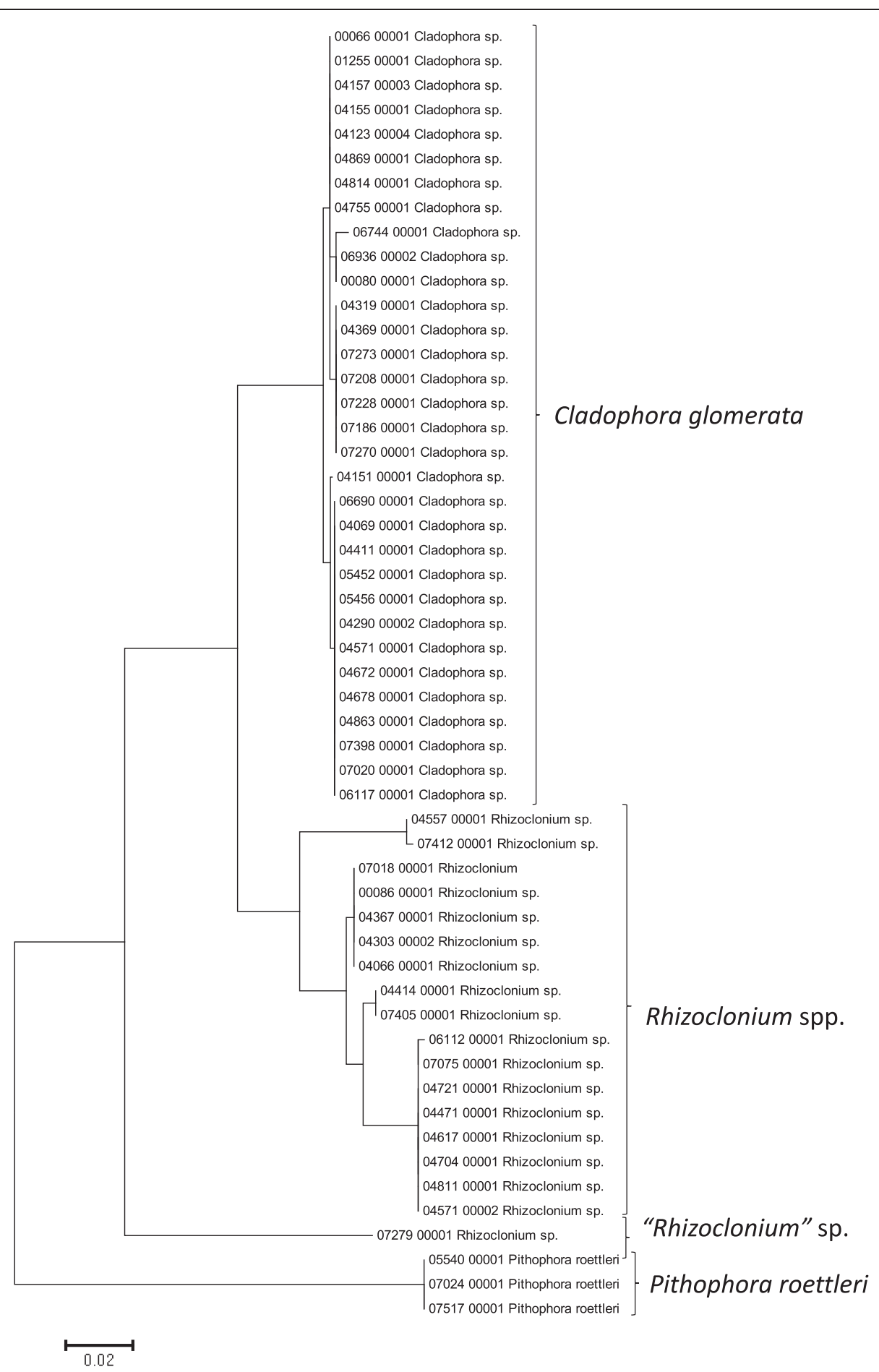

Figure 9 Neighbor-joining tree of LSU sequences of the Hawaiian non-marine, non-charophycean green algae. Sequence diversity based on the LSU marker for the Hawaiian non-marine, non-charophycean green algae. The neighbor-joining tree is based on uncorrected p-distances nucleotide model in MEGA 5.05. Scale bar= substitutions per site.

macroalgae across the Hawaiian Islands in numerous publications dating back to 1876 [14-16,69], and our survey collections of this genus spanned 86 locations on six islands, including diverse habitats such as streams, ditches, taro fields, bogs and ponds. The red algal "form genus" Chantransia was previously thought to be represented in the Hawaiian Islands by two lineages, Sheathia arcuata and Nemalionopsis shawii [70]; however, two 


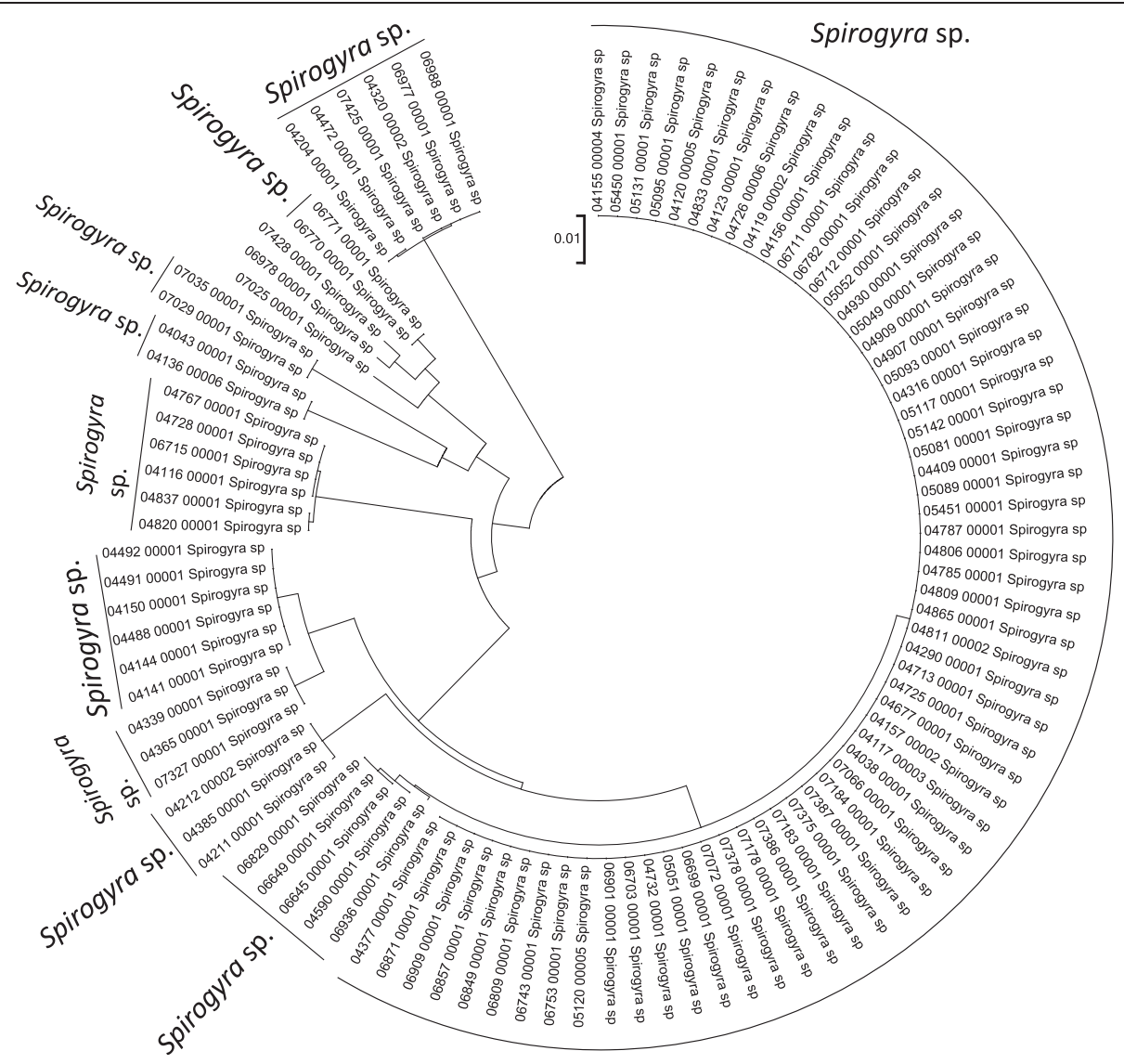

Figure 10 Neighbor-joining tree of $r b c L$ sequences of the Hawaiian non-marine charophycean green algae. Sequence diversity based on the $r b c L$ marker for the Hawaiian non-marine charophycean green algae. The neighbor-joining tree is based on uncorrected p-distances nucleotide model in MEGA 5.05. Scale bar = substitutions per site.

additional taxa were added as a result of the survey collections (Thorea hispida and an undescribed Thorea sp.), doubling the known diversity of these freshwater red algal sporophytes in Hawaii [39]. Some non-marine representatives of the Cladophorales (Cladophora and Rhizoclonium), which can be difficult or impossible to identify using only morphological characters were demonstrated in some cases to be molecularly homogeneous, as demonstrated by others, despite substantial morphological variation (i.e. freshwater Cladophora [71]), and in other cases to harbor genus-level molecular diversity masked by a simple morphology (i.e. Rhizoclonium; A. Havens, A. Carlile \& A. Sherwood, personal observations). Thus, one of the most valuable outcomes of the biodiversity survey approach of collecting and characterizing all non-marine macroalgae from a geographical region is that it allows multi-taxon large scale comparisons that can be compared to more accurately assess taxonomy and infer broader distributional patterns.

Biogeographic patterns of the Hawaiian non-marine algae Baas Becking's ideas of microorganisms being globally distributed apply to organisms too small to see with the unaided eye, yet may be applicable to the study of freshwater macroalgae given that the dispersal forms of these organisms (spores, fragments, etc.) fall into the $<1 \mathrm{~mm}$ size range (Figures 16 and 17). As a consequence, organism size may not predict distribution patterns well. Dispersal mechanisms of non-marine algae have been the subject of much speculation but little empirical research. A number of means of transport have been proposed, including air currents, vector-assisted transport (e.g. on the feet or feathers of birds, in the guts of fish or cases of aquatic invertebrates, via anthropogenic means), or rafting [72-74]. Although the initial colonization of the volcanically produced Hawaiian Islands by non-marine algae must have occurred by long-distance transport [4], dispersal among the islands likely played an increasingly important role in shaping the flora of the archipelago.

The non-marine algal flora of the Hawaiian Islands has almost certainly been impacted by humans since their first arrival in the Islands (between 400-1100 AD [2]). Polynesian introductions of numerous plant species for food and other uses may account for the first anthropogenic changes to the flora, but an acceleration of 


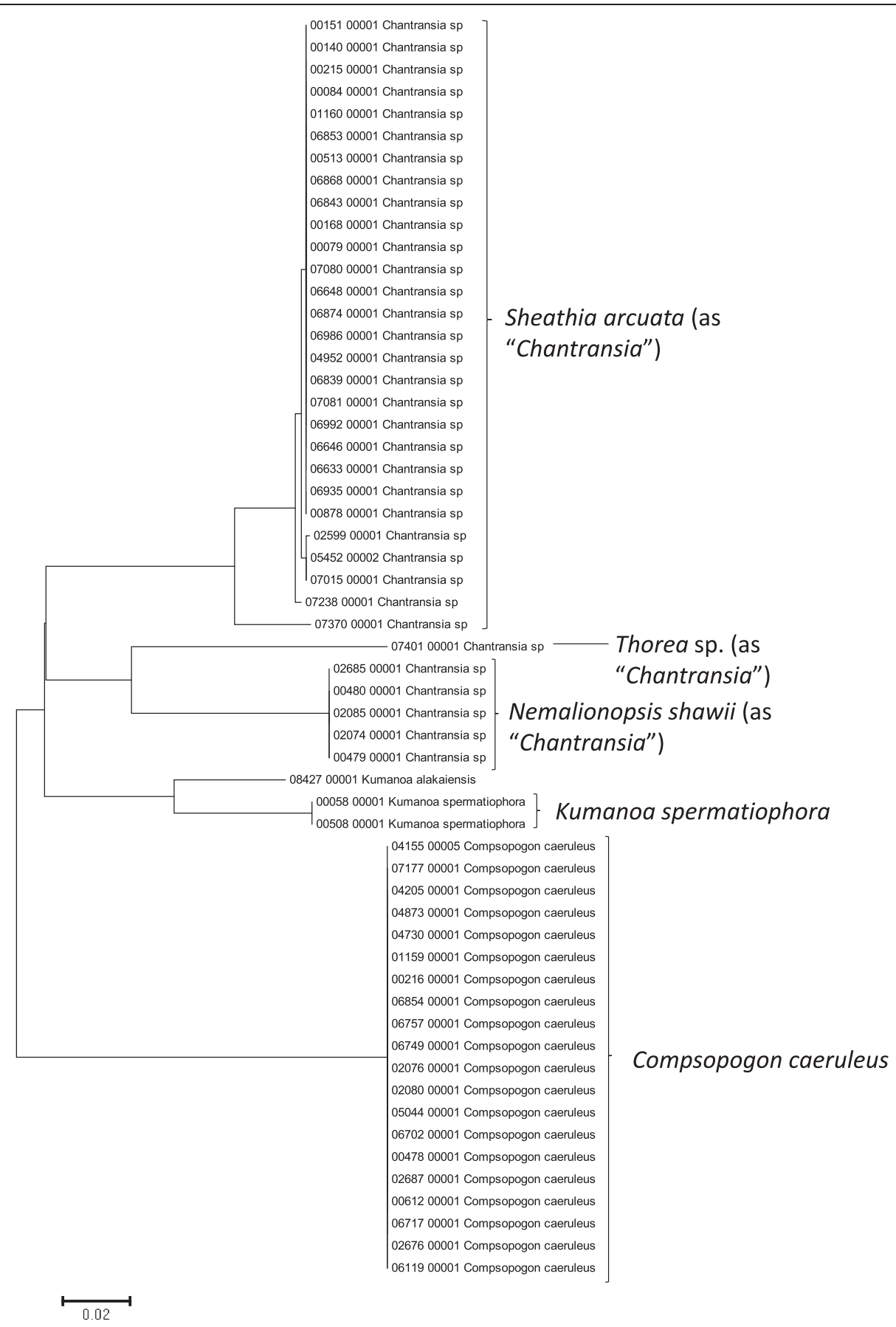

Figure 11 Neighbor-joining tree of $r b c L$ sequences of the Hawaiian non-marine red algae. Sequence diversity based on the $r b c L$ marker for the Hawaiian non-marine red algae. The neighbor-joining tree is based on uncorrected p-distances nucleotide model in MEGA 5.05. Scale bar= substitutions per site.

human impact over the past several hundred years (European contact in 1778 [2]) has probably had an even greater influence its composition, with spores and fragments being transported to and among the islands from activities such as the aquarium and ornamental plant trades, hiking, transport of building materials and heavy machinery, and farming. Any attempts to interpret algal biogeographic patterns must take these influences into consideration.

What is evident from the survey collection analyses is that no consistent biogeographic pattern emerges to explain the origins of the non-marine algal flora of the Hawaiian Islands. Some remarkably widespread taxa were characterized that are also known from many locations worldwide, 


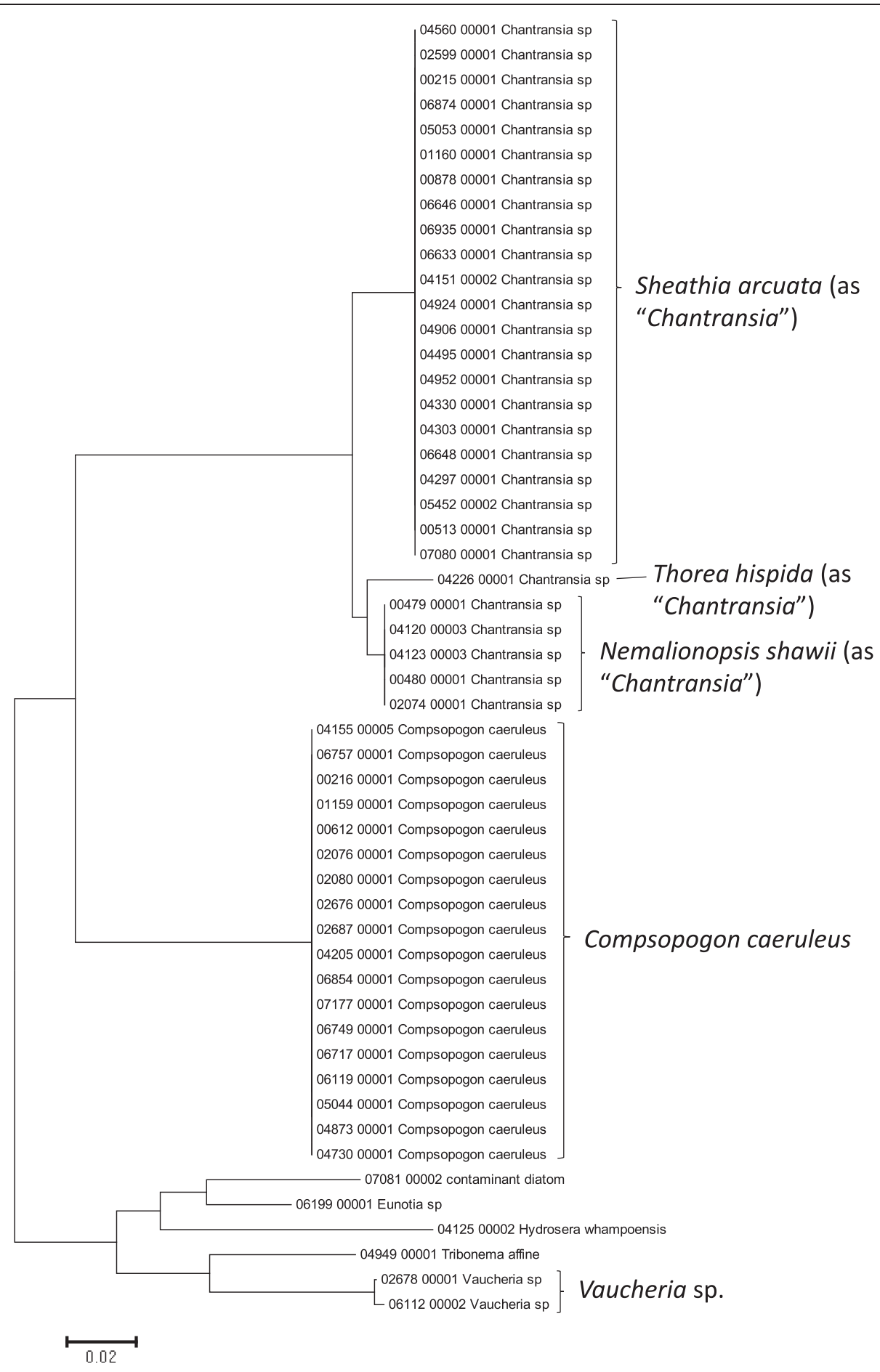

Figure 12 Neighbor-joining tree of SSU sequences of the Hawaiian non-marine red algae, diatoms and xanthophyte algae. Sequence diversity based on the SSU marker for the Hawaiian non-marine red algae, diatoms and xanthophyte algae. The neighbor-joining tree is based on uncorrected p-distances nucleotide model in MEGA 5.05. Scale bar = substitutions per site.

including the clonally propogating red alga Compsopogon caeruleus and the green alga Cladophora glomerata; distribution of the former to Hawaii may be a result of the aquarium trade [39], while ubiquity in the latter case may be a result of either anthropogenic or non-anthropogenic dispersal. A few taxa were demonstrated to consist of multiple, cryptic lineages that likely represent intraspecific taxonomic variation, including Sheathia arcuata and some 


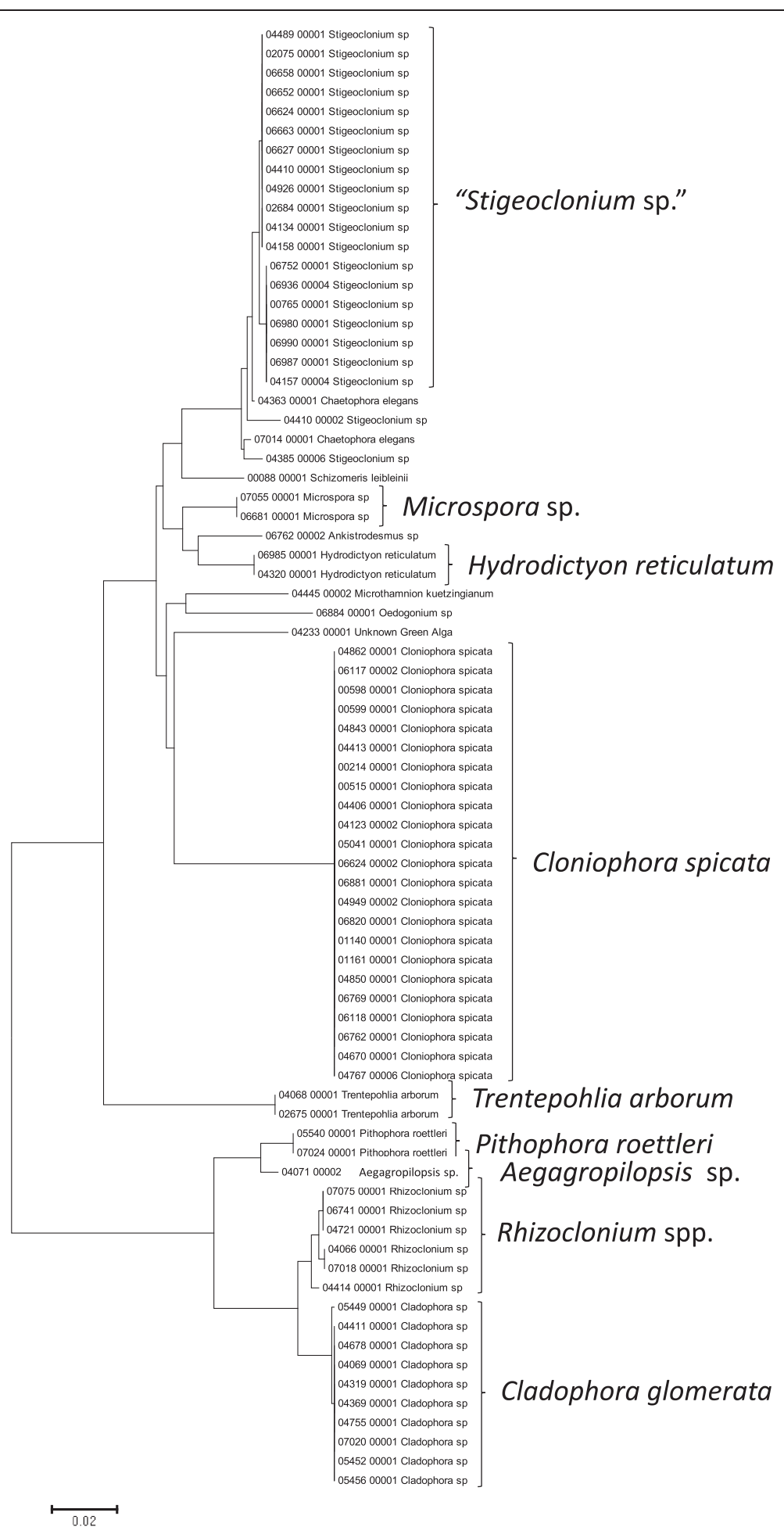

Figure 13 Neighbor-joining tree of SSU sequences of the Hawaiian non-marine, non-charophycean green algae. Sequence diversity based on the SSU marker for the Hawaiian non-marine, non-charophycean green algae. The neighbor-joining tree is based on uncorrected p-distances nucleotide model in MEGA 5.05. Scale bar = substitutions per site. 


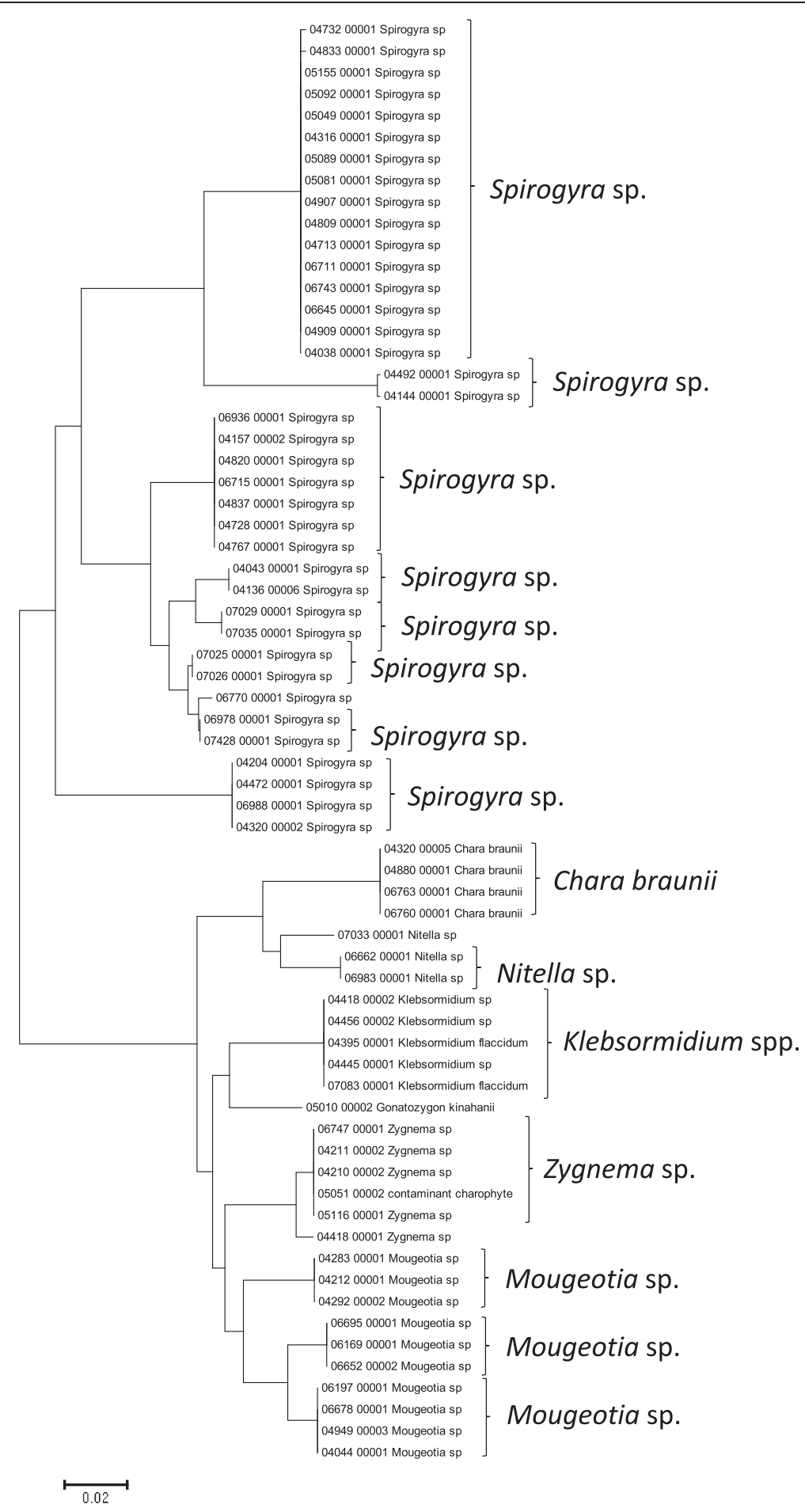

Figure 14 Neighbor-joining tree of SSU sequences of the Hawaiian non-marine, charophycean green algae. Sequence diversity based on the SSU marker for the Hawaiian non-marine charophycean green algae. The neighbor-joining tree is based on uncorrected p-distances nucleotide model in MEGA 5.05. Scale bar = substitutions per site.

Spirogyra spp. A number of other taxa were found to have affinities with samples from a more limited number of other regions, but with little obvious biogeographical connection, for example, Cloniophora spicata, Nemalionopsis shawii, Pithophora roettleri, Schizomeris leiblienii and Thorea hispida ([39], this study). In the absence of well-populated reference frameworks of collections from numerous locations it seems likely that these distributions 
are a product of under-sampling rather than being representative of true biogeographic patterns. Conversely, several taxa were identified that are currently considered endemic to the Hawaiian Islands (e.g. Kumanoa alakaiensis, K. spermatiophora, Nostochopsis n.sp., Scytonematopsis contorta, Thorea n.sp.), and it is possible that expanded distributions of these taxa may be recognized in the future with increased sampling and characterization of the non-marine algal floras of other tropical Pacific Islands. It should also be noted that a number of microalgal taxa have also been recently described from the Hawaiian Islands as a result of this biodiversity survey, which serves to further emphasize the rich flora of this archipelago that is being illuminated through this opportunity for focused taxonomic attention [41,75-77].

Accurate taxonomic identification of algae is not straightforward, and much depends on the species concept employed. Many of the taxa reported in this survey were described decades, if not centuries ago, and the formal descriptions of these taxa are anchored in morphological characters. While a great deal of information can be gleaned from macroscopic and microscopic observation, over the past two decades numerous examples of cryptic and pseudo-cryptic variation in algae have been 


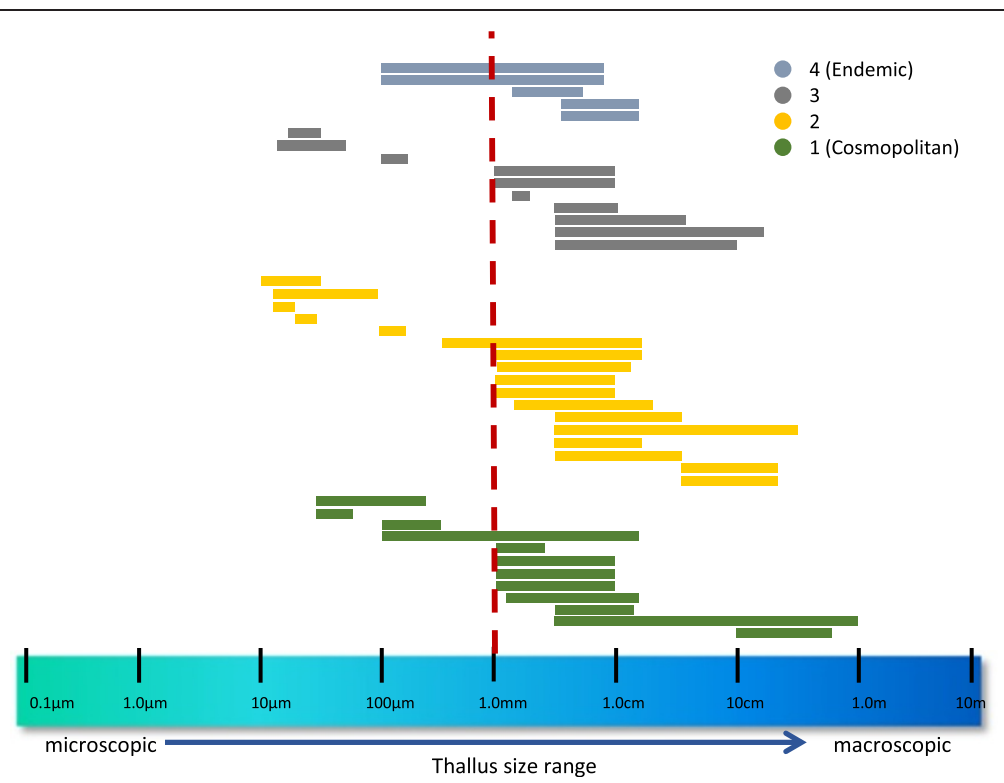

Figure 16 Graphical representation of thallus size by category of distribution. Graphical representation of thallus sizes of well-characterized Hawaiian non-marine algae, separated by category of distribution (as given for Figure 15).

highlighted through the analysis of molecular data [78,79], and a definitive application of a pre-existing taxonomic name can only be made in light of demonstrated molecular affinity with type material; an exhausting and impossible prospect for the plethora of collections resulting from a biodiversity survey. Thus, it is expected that the taxonomic names applied to Hawaiian non-marine algae will be revisited and re-examined as more comparative data become available. Finally, several practical difficulties played into a tradeoff between the number of samples that could be characterized and the number for which species-level taxonomic names could be applied. Most non-marine algal collections were relatively small in size $(<2 \mathrm{~cm}$ in length) and were often heavily epiphytized; obtaining sufficient amounts of clean material for DNA extraction and PCR amplification was challenging. Additionally, many of the common taxa are typically assigned taxonomic names based heavily on characters pertaining to sexual reproduction (e.g. Oedogonium, Mougeotia, Spirogyra, Zygnema [80-83]), which was very infrequently observed in the field-collected

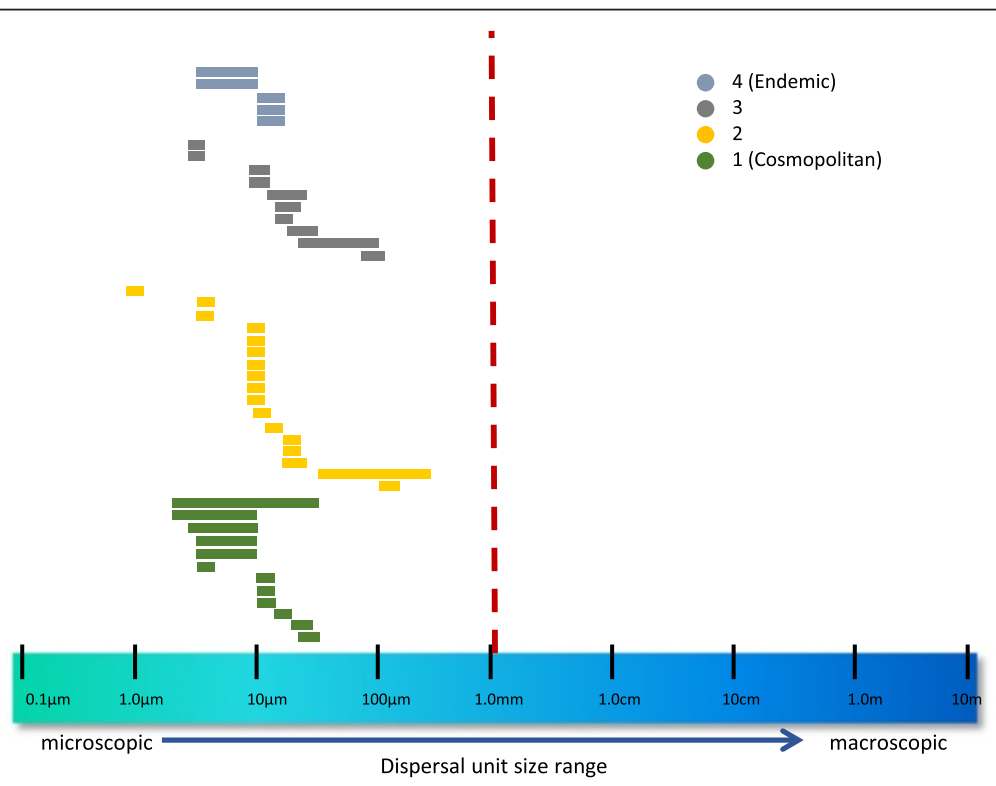

Figure 17 Graphical representation of dispersal-unit sizes by category of distribution. Graphical representation of dispersal-unit sizes of well-characterized Hawaiian non-marine algae, separated by category of distribution (as given for Figure 15). 
samples. Attempts to induce sexual reproduction in culture in the laboratory were frequently unsuccessful; these observations suggest that sexual reproduction in Hawaiian nonmarine algae may naturally occur much less frequently than for those in other geographical locations.

\section{Conclusions}

The Hawaiian Freshwater Algal Biodiversity Survey yielded the largest sequence data compilation yet for tropical nonmarine algae, which will serve as a baseline for comparison of new collections within the Hawaiian Islands and to other tropical regions. Key features of the biodiversity survey include the following: 1) The Hawaiian Freshwater Algal Database, which includes data for both collection sites and individual algal samples, which was designed and implemented as a key organizational component of the study, and serves as a web-accessible project portal to the scientific and broader communities. These kinds of digital resources are becoming increasingly recognized as critical data sources to those extracting and compiling broader scale patterns [84]. 2) Analysis of the 1,786 collecting sites and resultant 1,407 macroalgal samples, which informed the construction of the first comprehensive checklists for non-marine algae from unusual habitats in the Hawaiian Islands (taro fields and bogs [49,50]), and an updated taxonomic checklist of Hawaiian non-marine macroalgae (Additional file 1). 3) In-depth assessment of common Hawaiian taxa, including representatives of the green algae (Cloniophora, Spirogyra, members of the Chaetophoraceae and Cladophoraceae), red algae (Compsopogon, Chantransia forms of Nemalionopsis, Sheathia and Thorea) and several cyanobacteria (e.g. Nostoc and Nostochopsis). Future research characterizing other tropical non-marine algal floras is needed to be able to draw comparisons between the flora of the Hawaiian Islands and elsewhere, to foster an understanding of the level of endemism in these isolated systems, and to illuminate the biodiversity of these understudied components of tropical island floras.

\section{Methods}

\section{Sampling strategy and taxonomic scope}

Samples were field-collected during five multi-island expeditions (July 2009, January 2010, May 2010, January 2011 and January 2012), and numerous smaller collecting trips to individual islands. Islands yielding substantial diversity were collected multiple times (Kauai, Oahu, Maui and Hawaii), while those with either limited diversity or a limited number of accessible habitats were collected only once (Molokai and Lanai). Expeditions were planned for different times of the year to capture some of the seasonality inherent in the wet-dry alternation of seasons in the Hawaiian Islands. All non-marine habitats were targeted, including streams, wet walls (drippy vertical surfaces that are not influenced by sea spray; typically associated with streams and waterfalls), high elevation bogs, taro fields (agricultural fields dedicated to cultivation of wetland taro plants), ditches and flumes (which were commonly constructed in the Hawaiian Islands for water transport for large-scale agriculture), lakes/reservoirs, cave walls and terrestrial areas (such as roadsides, damp ground, cement surfaces, etc.). Sampling sites were not selected randomly, but based on a combination of accessibility and likelihood of yielding interesting algae. Samples were collected from streams, bogs, taro fields, ditches and flumes using a glass-bottomed view box and long-handled forceps or a turkey-baster, while those from other habitats were collected by directly viewing the substratum and collecting the sample with forceps or scraping it with a spoon or razor blade. Samples were kept in WhirlPak ${ }^{\mathrm{TM}}$ bags until processed in the laboratory. All macroalgae (i.e. algae that could be seen with the naked eye, either as individuals or in colonial form) were targeted for this component of the survey, including both eukaryotic and cyanobacterial taxa. Some microalgal identifications were included when they were identified as part of a macroalgal collection (i.e. during surveys of taro field or high elevation bog habitats). Many more microalgal collections were made during the survey than are presented here - these will be published under separate taxonomic treatments by the co-authors of this study specializing in microalgal taxonomy. Each distinct site that was collected was given a five-digit "environmental accession" number, and the WhirlPak ${ }^{\mathrm{TM}}$ bag containing the algal material from that site was labeled with that number.

\section{Sample processing and analysis}

Environmental samples were examined live with instructional-grade compound light microscopes (e.g. Wolfe B3 series) taken on inter-island collecting expeditions, and samples were divided so that diatoms, microscopic soft algae, and cyanobacteria could be studied in detail in the respective laboratories of various members of the collection team. The remainder of the environmental accession material, which included the macroalgae, was examined with a stereomicroscope (Zeiss SteREO Discovery v12) in the Sherwood laboratory on Oahu and individual taxa were cleaned and preserved for molecular study (by desiccating in silica gel or freezing at $-20^{\circ} \mathrm{C}$ ) and/or isolated for culturing. Environmental samples were initially placed in $60 \times 15 \mathrm{~mm}$ petri dishes in a WC/L1 modified media, which consisted of a WC media base [85] and L1 trace metals solution [86]. Individual strains were isolated through serial dilution into either 24- or 96-well culture plates and subsequent micromanipulation into subcultures until unialgal cultures with enough material for molecular and morphological characterizations were obtained [87]. Cultures were maintained at room temperature $\left(21-24^{\circ} \mathrm{C}\right)$ under approximately $100-250 \mu \mathrm{mol} / \mathrm{sec} / \mathrm{m}^{2}$ PAR, conditions typical for those in Hawaiian freshwater 
systems where samples were collected $[88,89]$. All remaining material was fixed in $2.5 \% \mathrm{CaCO}_{3}$-buffered glutaraldehyde in $20-\mathrm{mL}$ scintillation vials and is currently held $\left(\right.$ at $4^{\circ} \mathrm{C}$ ) in the Sherwood laboratory at the University of Hawaii. Fixed material was examined with a compound light microscope (Olympus BX-41 or Zeiss AxioImager A1), and duplicate semi-permanent corn syrup microscope slides were made as vouchers. For a few of the larger taxa (e.g. Characeae), herbarium sheets were made. Morphological characters were compared to those in the phycological literature $[80-83,90,91]$ and references within), and an identification to the lowest possible taxonomic level was assigned. In many cases the characters necessary for species-level (or, in some cases, even genus-level) identification were not present in the field-collected material (e.g., those pertaining to sexual reproduction, which was not commonly observed in the samples). For each identification, an accession number was assigned (the "isolate accession"), which consisted of ten digits - the first five of which comprised the environmental accession, and the second five of which indicated the number of the taxon isolated or identified (e.g. isolate accession 04380-00001 indicates the first taxon identified from environmental sample 04380).

DNA was extracted from field-collected and cultured material using a Qiagen DNeasy Plant Mini Kit. One primary aim of the project was to generate and compare baseline molecular marker sequences for as many taxa as possible, and thus one or two markers were sequenced for all or most samples (UPA and SSU), with additional markers selected based on available comparative data and the level of systematic investigation deemed necessary (see Table 1 for a list of primers used and references for PCR cycling conditions). All samples were amplified via PCR for the UPA marker [61,92], while the partial SSU marker was subsequently added as a universal marker for all eukaryotic samples, and several additional markers (e.g. COI, $r b c L, 16 \mathrm{~S}$ rRNA, LSU, tufA) were used for lineagespecific taxonomic or phylogeographic investigations. PCR product purification and sequencing followed Carlile \& Sherwood [39]. Cyanobacterial 16S rRNA sequences were cloned (1-3 clones per taxon) following Vaccarino \& Johansen [40]; clones are indicated in phylogenetic analyses with the suffix "a", "b", or "c" following the isolate accession.

\section{Data storage and dissemination}

All associated sample and collection site data (photographs and micrographs, locality information, taxonomic identifications, DNA sequences, voucher type and archival information) were entered into the Hawaiian Freshwater Algal Database (HfwADB), which was modeled after the Hawaiian Algal Database (HADB) and built specifically to organize and display the project data. $\mathrm{H} f w \mathrm{ADB}$ is described in full [95] and is internet accessible at http:// algae.manoa.hawaii.edu/hfwadb. HfwADB holds images and other relevant data for both "environmental accessions" (i.e. georeferenced collection sites) and "isolate accessions" (i.e. individual algal identifications and their associated data, including micrographs and DNA sequence data).

Table 1 Primers and references for PCR amplification conditions of markers employed in the current study

\begin{tabular}{|c|c|c|c|c|}
\hline Marker & Source & Primers & Reference(s) & Taxa characterized \\
\hline $16 \mathrm{~S}$ rRNA & Cyanobacterial genome & $\begin{array}{l}\text { Primer } 1 \text { (5' CTC TGT GTG CCT AGG TAT CC 3') and Primer } 2 \\
\text { (5' GGG GAA TTT TCC GCA ATG GG 3') }\end{array}$ & [51] & Cyanobacteria \\
\hline $\mathrm{COI}$ & Mitochondrial & $\begin{array}{l}\left.\text { GazF1 (5' TCA ACA AAT CAT AAA GAT ATT GG } 3^{\prime}\right) \text { and GazR1 } \\
\text { (5' ACT TCT GGA TGT CCA AAA AAY CA 3') }\end{array}$ & {$[52]$} & Rhodophyta \\
\hline ITS & Nuclear & $\begin{array}{l}\text { CladolTS-9 F (5' CCG CCC GTC GCT CCT ACC GAT TGG GTG TG 3') } \\
\text { and CladolTS7R (5' TCC CTT TTC GCT CGC CGT TAC TA 3') }\end{array}$ & [93] & Chlorophyta \\
\hline LSU & Nuclear & $\begin{array}{l}C^{\prime} 1 \text { ( } 5^{\prime} \text { ACC CGC TGA ATT TAA GCA TAT 3') and D2 (5' TCC GTG } \\
\text { TाT CAA GAC GG 3'); C1FL (5' ACC CGC TGA ACT TAA GC 3') and } \\
\text { D2FL (5' GGT CCG TGT TTC AAG 3') }\end{array}$ & {$[53,54]$} & Chlorophyta \\
\hline SSU & Nuclear & $\begin{array}{l}\text { SR4 (5' AGC CGC GGT AAT TCC AGC T 3') and SR9 (5' AAC } \\
\left.\text { TAA GAA CGG CAT GCA C } 3^{\prime}\right)\end{array}$ & [94] & All eukaryotic lineages \\
\hline$r b c L$ & Plastid & $\begin{array}{l}\text { F160 (5' CCT CAA CCA GGA GTA GAT CC 3') and rbcLR } \\
\text { (5' ACA TIT GCT GTT GGA GTC TC 3') (Rhodophyta); Comp1 } \\
\text { (5' GAA TCT TCT ACA GCA ACT TGG AC 3') and Comp } 2 \\
\text { (5' GCA TCT CTT ATT ATT TGA GGA CC 3') (Rhodophyta); RH1 } \\
\text { (5' ATG TCA CCA CAA ACA GAA ACT AAA GC 3') and rbCL-R1351- } \\
\text { Zyg (5' AGC AGC TAA TTC AGG ACT CAA 3') (Streptophyta) }\end{array}$ & {$[55-57]$} & Rhodophyta and Streptophyta \\
\hline tufA & Plastid & $\begin{array}{l}\left.\text { tufAF (5' TGA AAC AGA AMA WCG TCA TTA TGC } 3^{\prime}\right) \text { and tufAR } \\
\left(5^{\prime} \text { CCT TCN CGA ATM GCR AAW CGC 3') }\right.\end{array}$ & {$[58]$} & Streptophyta and Chlorophyta \\
\hline UPA & Plastid & $\begin{array}{l}\left.\text { p23SrV_f1 (5' GGA CAG AAA GAC CCT ATG AA } 3^{\prime}\right) \text { and } \\
\left.\text { p23SrV_r1 (5' TCA GCC TGT TAT CCC TAG AG } 3^{\prime}\right)\end{array}$ & [61] & All lineages \\
\hline
\end{tabular}




\section{Data analyses Mapping}

Environmental accession (i.e. locality) data were downloaded from $\mathrm{H} f \mathrm{~A} \mathrm{ADB}$ and plotted on a map of the Main Hawaiian Islands using GPS Visualizer (http://www. gpsvisualizer.com/).

\section{DNA barcoding}

Sequences of each marker were downloaded from $\mathrm{H} f w \mathrm{ADB}$ and aligned using Clustal X [96]. Neighbor-joining (NJ) trees for the 16S rRNA, COI, LSU, SSU, $r b c L$, and UPA markers were constructed using uncorrected $\mathrm{p}$-distances in MEGA v. 5.05 [97] to examine patterns of molecular diversity. The NJ trees are presented as a visual display of the quantity and nucleotide variation in DNA sequences of Hawaiian non-marine algae. Although some authors are now electing to omit tree-based DNA barcode comparisons and present sequence divergences in tabular form [98], NJ trees are included here as a more easily interpretable display of the sequence data gathered and compared for this survey. Only a small number of closely-related taxa were sequenced for the ITS ( $\mathrm{n}=5$; Cloniophora and Stigeoclonium) and tufA ( $\mathrm{n}=7$; Cloniophora) markers, hence summaries of those sequences are not shown here. Summary labels were added to the tree figures to indicate proposed taxonomic boundaries. Occasionally sequences were obtained that did not phylogenetically correspond to the intended taxon; in these cases the sequences were entered into $\mathrm{H}$ fw $\mathrm{ADB}$ with the designation "contaminant sequence", and these are included in the DNA barcoding analyses as an additional indication of Hawaiian algal diversity.

\section{Categories of distribution}

Taxa determined to be well-characterized at the species level were further investigated for patterns of distribution. All taxa identified in the survey that were confidently identified to the level of species, and for which a species name could be applied, were queried through AlgaeBase (www.algaebase.org) [99] as well as the primary literature for distributional records. Distributions (presence/absence) were recorded by Hawaiian Island, and subsequently for each of the following broad geographic regions: Pacific Islands, Australia and New Zealand, Asia, North America, the Caribbean, South America, Europe, and Africa. To infer the degree of endemism versus cosmopolitanism for the Hawaiian freshwater algal flora, taxa were binned as belonging to one of four categories of distribution, and then compared to other members of the flora. The four categories employed were 1) those taxa reported from six or more regions outside of Hawaii (i.e. cosmopolitan, or approaching cosmopolitan in distribution), 2) 4-5 other regions, 3) 1-3 other regions, and 4) within-Hawaii only (i.e. putatively endemic to the Hawaiian Islands). Taxa classified into one of the four categories were further investigated in the literature to obtain thallus size range and "dispersal unit" (i.e., motile cells, gametes, fragments, etc.) size range; these values were graphically compared across distributional categories.

\section{Availability of supporting data}

The data sets supporting the results of this article are available in the Dryad repository, doi:10.5061/dryad.ns1m7, and in GenBank [KM676560 - KM676564 for ITS, KM676565 KM676567 for tufA, KM676568 - KM676828 for UPA, KM676829 - KM676881 for LSU, KM676882 - KM677026 for SSU, KM677027 - KM677127 for $r b c L]$.

\section{Additional files}

Additional file 1: Hawaiian non-marine algal checklist. Checklist of non-marine algae collected and identified as part of the Hawaiian Freshwater Algal Biodiversity Survey.

Additional file 2: List of taxon names, in order, belonging to each distributional category illustrated in Figures 16 and 17.

Competing interests

The authors declare that they have no competing interests.

\section{Authors' contributions}

ARS wrote the initial draft of the manuscript, co-conceived of the study, and participated in its design, execution and coordination. ALC, JMN and KYC participated in the field work and coordination of the study and generated the molecular data. JPK, JJ, RLL and GGP participated in the design, coordination and field work of the study. ARS, JPK, JJ, RLL and GGP obtained funding. All authors read and approved the final manuscript.

\section{Acknowledgements}

This research was funded by a grant from the National Science Foundation (DEB-841734) to support the Hawaiian Freshwater Algal Biodiversity Survey. Many thanks to Norman Wang and Thomas Wolfgruber for implementing and maintaining the Hawaiian Freshwater Algal Database, and for providing data downloads. We thank Melissa and Christine Vaccarino, Carrie Graeff, Laura Miscoe and Alex Valigosky for collecting assistance.

\section{Author details}

'Department of Botany, University of Hawaii, 3190 Maile Way, Honolulu, HI 96822, USA. ${ }^{2}$ Current address: Department of Biology and Environmental Science, University of New Haven, 300 Boston Post Road, West Haven, CT 06516, USA. ${ }^{3}$ Department of Ecology and Evolutionary Biology and Museum of Natural History, University of Colorado, Boulder, CO 80309, USA.

${ }^{4}$ Department of Biology, John Carroll University, University Heights, $\mathrm{OH}$ 44118, USA. ${ }^{5}$ Department of Biological Sciences, Bowling Green State University, Bowling Green, $\mathrm{OH} 43409$, USA. ${ }^{6}$ Department of Molecular Biosciences and Bioengineering, University of Hawaii, 1955 East-West Road, Honolulu, HI 96822, USA

Received: 18 June 2014 Accepted: 9 October 2014

Published online: 25 October 2014

\section{References}

1. Juvik SP, Juvik JO: Atlas of Hawaii. 3rd edition. Honolulu: University of Hawaii Press; 1998.

2. Zeigler AC: Hawaiian Natural History, Ecology, and Evolution. Honolulu: University of Hawaii Press; 2002

3. Carson HL, Clague DA: Geology and Biogeography of the Hawaiian Islands. In Hawaiian Biogeography: Evolution on a Hotspot Archipelago. Edited by Wagner WL, Funk VA. Washington and London: Smithsonian Institution Press; 1995:14-29. 
4. Wagner WL, Funk VA: Preface. In Hawaiian Biogeography: Evolution on a Hotspot Archipelago. Edited by Wagner WL, Funk VA. Washington and London: Smithsonian Institution Press; 1995:ix-xi.

5. Ford Jl, Kinzie RA III: Life crawls upstream. Nat Hist 1982, 91:61-66.

6. Evenhuis NL, Eldredge LG: Hawaii's biodiversity: a detailed assessment of the numbers of species in the Hawaiian Islands. Bish Mus Occ Pap 2003, 76:1-28.

7. Knope ML, Morden CW, Funk VA, Fukami T: Area and the rapid radiation of Hawaiian Bidens (Asteraceae). J Biogeogr 2012, 39:1206-1216.

8. Morden CW, Ching-Harbin S: Evolution and Biogeographic origins of the Endemic Hawaiian Genus Hesperomannia (Asteraceae). Pac Sci 2013 67:219-235.

9. Vernon AL, Ranker TA: Current status of the ferns and lycophytes of the Hawaiian Islands. Am Fern J 2013, 103:59-111.

10. Lemmerman E: Die Algenflora der Sandwich-Inseln. Ergebnisse einer Reise nach dem Pacific. H. Schauinsland 1896/97. Bot Jahrb Syst Pflanzengesch Pflanzengeogr 1905, 34:607-632.

11. Tilden JE: Algae collecting in the Hawaiian Islands. Postelsia 1901, 1:135-175.

12. Tilden JE: Collection of algae from the Hawaiian Islands. Hawaii Ann 1902, 1902:106-113.

13. Tilden JE: Minnesota algae, Volume 1. The Myxophyceae of North America and adjacent regions including Central America, Greenland, Bermuda, the West Indies and Hawaii. Minneapolis: Report of the Survey Botanical Series VIII; 1910.

14. MacCaughey V: The phytogeography of Manoa Valley, Hawaiian Islands. Am J Bot 1917, 4:561-603.

15. MacCaughey V: Algae of the Hawaiian Archipelago I. Bot Gaz 1918, 65:42-57.

16. MacCaughey V: Algae of the Hawaiian Archipelago II. Bot Gaz 1918, 65:121-149.

17. Hustedt FT: Süsswasser-Diatomeen des indomalayischen Archipels und der Hawaii-Inseln. Int Rev Ges Hydrobiol Hydrogr 1942, 42:1-252.

18. Fungladda N, Kaczmarska I, Rushforth SR: A contribution to the freshwater diatom flora of the Hawaiian Islands. Biblioth Diatomol 1983, 2:1-103.

19. Rushforth SR, Kaczmarska I, Johansen JR: The subaerial diatom flora of Thurston Lava Tube, Hawaii. Bacillaria 1984, 7:135-157.

20. Vis ML, Sheath RG, Hambrook JA, Cole KM: Stream macroalgae of the Hawaiian Islands: a preliminary study. Pac Sci 1994, 48:175-187.

21. Sherwood AR: Bibliographic checklist of the non-marine algae of the Hawaiian Islands. Bish Mus Occ Pap Ser 2004, 80:1-23.

22. Abbott IA: Marine Red Algae of the Hawaiian Islands. Honolulu: Bishop Museum Press; 1999

23. Sherwood AR: Where are we now regarding Hawaiian stream algal systematics? (A suspiciously cosmopolitan flora). Bish Mus Bull Cul Envir Stud 2007, 3:195-206.

24. Tyler PA: Endemism in freshwater algae. In Biogeography of Freshwater Algae. Edited by Kristiansen J. Belgium: Kluwer Academic Publishers, Belgium; 1996:127-135

25. Baas Becking LGM: Geobiologie of inleiding tot de milieukunde. The Hague: W. P. Van Stockum \& Zoon; 1934.

26. Finlay BJ: Global dispersal of free-living microbial eukaryote species. Science 2002, 296:1061-1063.

27. Finlay BJ, Fenchel T: Cosmopolitan metapopulations of free-living microbial eukaryotes. Protist 2004, 155:237-244.

28. Kociolek JP, Spaulding SA: Freshwater diatom biogeography. Nov Hedwig 2000, 71:223-241.

29. Whitfield J: Biogeography: is everything everywhere? Science 2005, 310:960-961.

30. Šlapeta J, López-García P, Moreira D: Global dispersal and ancient cryptic species in the smallest marine eukaryotes. Mol Biol Evol 2006, 23:23-29.

31. Telford RJ, Vandvik V, Birks HJB: Dispersal limitations matter for microbial morphospecies. Science 2006, 312:1015.

32. Fontaneto $\mathrm{D}$, Hortal J: At least some protist species are not ubiquitous Mol Ecol 2013, 22:5053-5055.

33. Boo SM, Kim HS, Shin W, Boo GH, Cho SM, Jo BY, Kim J-W, Kim JH, Yang EC, Siver PA, Wolfe AP, Bhattacharya D, Andersen RA, Yoon HS: Complex phylogeographic patterns in the freshwater alga Synura provide new insights into ubiquity vs. endemism in microbial eukaryotes. Mol Ecol 2010, 19:4328-4338.

34. Souffreau C, Vanormelingen P, Van de Vijer B, Isheva T, Verleyen E, Sabbe K, Vyverman W: Molecular evidence for distinct Antarctic lineages in the cosmopolitan terrestrial diatoms Pinnularia borealis and Hantzschia amphioxys. Protist 2013, 164:101-115.

35. Dudgeon D, Arthington AH, Gessner MO, Kawabata Z-I, Knowler DJ, Lévêque C, Naiman RJ, Prieur-Richard A-H, Soto D, Stiassny MU, Sullivan CA: Freshwater biodiversity: importance, threats, status and conservation challenges. Biol Rev 2006, 81:163-182.

36. Strayer DL, Dudgeon D: Freshwater biodiversity conservation: recent progress and future challenges. J Nor Am Benthol Soc 2010, 29:344-358.

37. Geist J: Integrative freshwater ecology and biodiversity conservation. Ecol Indicat 2011, 11:1507-1516.

38. Carlile AL, O'Kelly CJ, Sherwood AR: The green algal genus Cloniophora represents a novel lineage in the Ulvales: a proposal for Cloniophoraceae fam. nov. J Phycol 2011, 47:1379-1387.

39. Carlile AL, Sherwood AR: Phylogenetic affinities and biogeography of the Hawaiian freshwater red algae (Rhodophyta). Phycologia 2013, 52:309-319.

40. Vaccarino MA, Johansen JR: Scytonematopsis contorta sp. nov. (Nostocales), a new species from the Hawaiian Islands. Fottea 2011, 11:149-161.

41. Kociolek JP, Stepanek JG, Lowe RL, Johansen JR, Sherwood AR: Molecular data show the enigmatic cave-dwelling diatom Diprora (Bacillariophyceae) to be a raphid diatom. Eur J Phycol 2013, 48:474-484.

42. Lobban CS, Daily WA, Hoshaw RW, Schefter M: Periphyton, excluding diatoms and desmids, from Yap, Caroline Islands. Micronesica 1990, 23:27-40.

43. Gerrath JF, Lobban CS: Desmids from Yap, Caroline Islands. Nov Hedw 1991, 52:173-195.

44. Sheath $\mathrm{RG}$, Cole KM: Stream macroalgae of the Fiji Islands: a preliminary study. Pac Sci 1996, 50:46-54

45. Filkin NR, Sherwood AR, Vis ML: Stream macroalgae of the Hawaiian Islands: 23 Additional Collection Sites. Pac Sci 2003, 57:421-431.

46. Sherwood AR, Englund RA: Freshwater algae collected during the 2002 Pacific Biological Survey, Bishop Museum Austral Island Expedition to Raivavae and Rapa, French Polynesia. Papeete: Report to the Délégation à la Recherche (Ministère de la Culture, de l'Enseignement Supérieur et de la Recherche); 2003.

47. Sherwood AR: Stream macroalgae of the Hawaiian Islands: a floristic survey. Pac Sci 2006, 60:191-205.

48. Zhao Z-J, Zhu H, Hu Z-Y, Liu G-X: Occurrence of true branches in Rhizoclonium (Cladophorales, Ulvophyceae) and the reinstatement of Rhizoclonium pachydermum Kjellman. Phytotaxa 2014, 166:273-284.

49. Sherwood AR, Carlile AL, Neumann JM: Freshwater algae associated with taro cultivation in the Hawaiian Islands. Bish Mus Occ Pap 2012, 113:81-85.

50. Sherwood AR, Carlile AL, Hall JD, Neumann JM: Freshwater algae associated with high elevation bogs in the Hawaiian Islands. Bish Mus Occ Pap 2013 114:21-31.

51. Boyer SL, Johansen JR, Flechtner VR, Howard GL: Phylogeny and genetic variance in terrestrial Microcoleus (Cyanophyceae) species based on sequence analysis of the 16S rRNA gene and associated 16S-23S ITS region. J Phycol 2002, 38:1222-1235.

52. Saunders GW: Applying DNA barcoding to red macroalgae: a preliminary appraisal holds promise for future application. Philos Trans $R$ Soc Lond B Biol Sci 2005, 360:1879-1888.

53. Leliaert F, Rousseau F, de Reviers B, Coppejans E: Phylogeny of the Cladophorophyceae (Chlorophyta) inferred from partial LSU rRNA gene sequences: is the recognition of a separate order Siphonocladales justified? Eur J Phycol 2003, 38:233-246.

54. Leliaert F, DeClerck O, Verbruggen H, Boedeker C, Coppejans E: Molecular phylogeny of the Siphonocladales (Chlorophyta; Cladophorophyceae). Mol Phylo Evol 2007, 44:1237-1256.

55. Rintoul TL, Sheath RG, Vis ML: Systematics and biogeography of the Compsopogonales (Rhodophyta) with emphasis on the freshwater families in North America. Phycologia 1999, 38:517-527.

56. Delwiche CF, Karol KG, Cimino MT, Sytsma KJ: Phylogeny of the genus Coleochaete (Coleochaetales, Charophyta) and related taxa inferred by analysis of the chloroplast gene rbcL. J Phycol 2002, 38:394-403.

57. Neumann JM: Biodiversity of Spirogyra and Sirogonium in the Hawaiian Islands: molecular insights into two morphologically similar macroalgal genera. MS thesis. Honolulu: University of Hawaii, Department of Botany; 2011.

58. Famà P, Wysor B, Kooistra WHCF, Zuccarello GC: Molecular phylogeny of the genus Caulerpa (Caulerpales, Chlorophyta) inferred from chloroplast tufA gene. J Phycol 2002, 38:1040-1050 
59. Sherwood AR, Kurihara A, Conklin KY, Sauvage T, Presting GG: The Hawaiian Rhodophyta Biodiversity Survey (2006-2010): a summary of principal findings. BMC Plant Biol 2010, 10:258.

60. Sherwood AR, Sauvage T, Kurihara A, Conklin KY, Presting GG: A comparative analysis of COI, LSU and UPA marker data for the Hawaiian florideophyte Rhodophyta: implications for DNA barcoding of red algae. Crypto, Algol 2010, 31:451-465.

61. Sherwood AR, Presting GG: Universal primers amplify a 23S rDNA plastid marker in eukaryotic algae and cyanobacteria. J Phycol 2007, 43:605-608.

62. Sherwood AR, Chan Y, Presting GG: Application of universal plastid primers to environmental sampling of a Hawaiian stream periphyton community. Mol Ecol Res 2008, 8:1011-1014.

63. Sherwood AR, Vis ML, Entwisle TJ, Necchi O Jr, Presting GG: Contrasting intra- versus inter-species DNA sequence variation for representatives of the Batrachospermales (Rhodophyta). Phycol Res 2008, 56:269-279.

64. Lam DW: Biodiversity and systematics of subaerial algae from the Neotropics and Hawaii. PhD thesis. University of Alabama Tuscaloosa, Department of Biology; 2010

65. Cockell CS, Rettberg P, Rabbow E, Olsson-Francis K: Exposure of phototrophs to 548 days in low Earth orbit: microbial selection pressure in outer space and on early earth. ISME 2011, 5:1671-1682.

66. Steven B, McCann S, Ward NL: Pyrosequencing of plastid 23S rRNA genes reveals diverse and dynamic cyanobacterial and algal populations in two eutrophic lakes. FEMS Microbiol Ecol 2012, 2012:1-9.

67. Taib N, Mangot J-F, Domaizon I, Bronner I, Debroas D: Phylogenetic affiliation of SSU rRNA genes generated by massively parallel sequencing: new insights into the freshwater protist diversity. PLoS One 2013, 8:e58950.

68. Dunthorn M, Otto J, Berger SA, Stamatakis A, Mahé F, Romac S, de Vargas C, Audic S, BioMarks Consortium, Stock A, Kauff F, Stoeck T: Placing environmental next-generation sequencing amplicons from microbia eukaryotes into a phylogenetic context. Mol Biol Evol 2014, 31:993-1009.

69. Nordstedt CFO: De Algae aquae dulcis de Characeis ex insulis Sandvicensibus a Sv. Berggren 1875 reportatis. Minesskr Fysisk Sallsk Lund 1876, 7:1-24.

70. Chiasson WB, Johansen KB, Sherwood AR, Vis ML: Phylogenetic affinities of the form taxon Chantransia pygmaea (Rhodophyta) specimens from the Hawaiian Islands. Phycologia 2007, 46:257-262.

71. Zulkifly SB, Graham JM, Young EB, Mayer RJ, Piotrowski MJ, Smith I, Graham LE: The genus Cladophora Kützing (Ulvophyceae) as a globally distributed ecological engineer. J Phycol 2013, 49:1-17.

72. Darwin C: On the Origin of Species by Means of Natural Selection. London: John Murray; 1859

73. Coleman AW: Are the impacts of events in the earth's history discernable in the current distributions of freshwater algae? In Biogeography of freshwater algae. Edited by Kristiansen J. Belgium: Kluwer Academic Publishers, Belgium; 1996:137-142.

74. Kristiansen J: Dispersal of freshwater algae - a review. In Dispersal of freshwater algae - a review. Edited by Kristiansen J. Belgium: Kluwer Academic Publishers, Belgium; 1996:151-157.

75. Lowe RL, Sherwood AR, Ress JR: Freshwater species of Achnanthes Bory (Bacillariophyta) from Hawaii. Diatom Res 2009, 24:327-340.

76. Lowe RL, Sherwood AR: Distribution and morphological variability of Cosmioneis (Bacillariophyceae) in Hawaii. Proc Acad Nat Sci Phil 2010, 160:21-28.

77. Ripple H, Kociolek JP: The diatom (Bacillariophyceae) genus Actinella Lewis in Hawaii. Pac Sci 2013, 67:609-621.

78. Kucera H, Saunders GW: A survey of Bangiales (Rhodophyta) based on multiple molecular markers reveals cryptic diversity. J Phycol 2012, 48:869-882

79. Moniz MBJ, Rindi F, Novis PM, Broady PA, Guiry MD: Molecular phylogeny of Antarctic Prasiola (Prasiolales, Trebouxiophyceae) reveals extensive cryptic diversity. J Phycol 2012, 48:940-955.

80. Prescott GW: Algae of the western Great Lakes area. Dubuque: Wm. C. Brown Publishers; 1951

81. Mrozińska T: Süßwasserflora von Mitteleuropa. Chlorophyta VI. Oedogoniophyceae: Oedogoniales. Jena: Gustav Fischer Verlag; 1985.

82. Wehr J, Sheath RG: Freshwater Algae of North America: Ecology and Classification. San Diego: Academic Press; 2002.
83. John DM, Whitton BA, Brook AJ: The Freshwater Algal Flora of the British Isles: An Identification Guide to Freshwater and Terrestrial Algae. Cambridge: Cambridge University Press; 2011

84. Shafer ABA, Cullingham Cl, Côté SD, Coltman DW: Of glaciers and refugia: a decade of study sheds new light on the phylogeography of northwestern North America. Mol Ecol 2010, 19:4589-4621.

85. Guillard RRL, Lorenzen CJ: Yellow-green algae with chlorophyllide c. J Phycol 1972, 8:10-14

86. Guillard RRL, Hargraves PE: Stichochrysis immobilis is a diatom, not a chrysophyte. Phycologia 1993, 32:234-236.

87. Anderson RA, Kawachi M: Traditional microalgae isolation techniques. In Algal Culturing Techniques. Edited by Anderson RA. New York: Elsevier Inc; 2005:83-100.

88. Larned ST, Santos SR: Light- and nutrient-limited periphyton in low order streams of Oahu, Hawaii. Hydrobiologia 2000, 432:101-111.

89. Anthony SS, Hunt CD Jr, Brasher AMD, Miller LD, Tomlinson MS: Water Quality on the Island of Oahu, Hawaii, 1999-2001. Honolulu: United States Geological Survey Circular; 2004:1239.

90. Kadłubowska JZ: Süßwasserflora von Mitteleuropa. Chlorophyta VIII, Zygnematales. Gustav Jena: Fischer Verlag; 1984.

91. Kumano S: Freshwater red algae of the world. Bristol: Biopress Ltd.; 2002

92. Presting GG: Identification of conserved regions in the plastid genome: implications for DNA barcoding and biological function. Can J Bot 2006 84:1434-1443.

93. Hayakawa Y, Ogawa T, Yoshikawa S, Ohki K, Kamiya M: Genetic and ecophysiological diversity of Cladophora (Cladophorales, Ulvophyceae) in various salinity regimes. Phycol Res 2012, 60:86-97.

94. Nakayama T, Watanabe S, Mitsui K, Uchida H, Inouye I: The phylogenetic relationship between the Chlamydomonadales and Chlorococcales inferred from 18S rDNA sequence data. Phycol Res 1996, 44:47-55.

95. Sherwood AR, Wang N, Carlile AL, Neumann JM, Wolfgruber TK, Presting GG: The Hawaiian Freshwater Algal Database (HfwADB): a laboratory LIMS and online biodiversity resource. BMC Ecol 2012, 12:22.

96. Larkin MA, Blackshields G, Brown NP, Chenna R, McGettigan PA, McWilliam $H$, Valentin F, Wallace IM, Wilm A, Lopez R, Thompson JD, Gibson TJ, Higgins DG: Clustal W and Clustal X version 2.0. Bioinformatics 2007, 23:2947-2948.

97. Tamura K, Peterson D, Stecher G, Nei M, Kumar S: MEGA5: Molecular Evolutionary Genetics Analysis using Maximum Likelihood, Evolutionary Distance, and Maximum Parsimony Methods. Mol Biol Evol 2011, 28:2731-2739

98. Saunders GW, McDevit D: A DNA barcode survey of Haida Gwaii kelp (Laminariales, Phaeophyceae) reveals novel ecological and distributional observations and Saccharina druehlii sp. nov. Botany. in press.

99. Guiry MD, Guiry GM: AlgaeBase. [http://www.algaebase.org]

\section{doi:10.1186/s12898-014-0028-2}

Cite this article as: Sherwood et al:: The Hawaiian freshwater algae biodiversity survey (2009-2014): systematic and biogeographic trends with an emphasis on the macroalgae. BMC Ecology 2014 14:28.

\section{Submit your next manuscript to BioMed Central and take full advantage of:}

- Convenient online submission

- Thorough peer review

- No space constraints or color figure charges

- Immediate publication on acceptance

- Inclusion in PubMed, CAS, Scopus and Google Scholar

- Research which is freely available for redistribution 